WATER-QUALITY STUDY OF TULPEHOCKEN CREEK, BERKS COUNTY, PENNSYLVANIA, PRIOR TO

IMPOUNDMENT OF BLUE MARSH LAKE

U.S. GEOLOGICAL SURVEY

Water-Resources Investigations 77-55

Prepared in cooperation with the

U.S. Army Corps of Engineers,

Philadelphia District 
BIBLIOGRAPHIC DATA SHEET

4. Title and Subtitle Water-Quality Study of Tulpehocken Creek,

Berks County, Pennsylvania, Prior to Impoundment of Blue Marsh Lake.

7. Author(s)

7. Author(s) James L. Barker

No.
9. Performing Organization Name and Address

U.S. Geological Survey, Water Resources Division

228 Walnut Street, P. O. Box 1107

Harrisburg, Pennsylvania 17108

12. Sponsoring Organization Name and Address

U.S. Geological Survey, Water Resources Division

228 Walnut Street, P. 0. Box 1107

Harrisburg, Pennsylvania 17108

15. Supplementary Notes

Prepared in cooperation with the U.S. Army Corps of Engineers, Philadelphia District

16. Abstracts Blue Marsh Lake is planned as a multipurpose impoundment to be constructed on Tulpehocken Creek near Bernville, Berks County, Pennsylvania. Prior to construction, samples of water, bed material, and soil were collected through-out the impoundment site to determine concentrations of nutrients, insecticides, trace metals, suspended sediment and bacteria. Analyses of water suggest the Tulpehocken Creek basin to be a highly fertile environment. Nitrogen and phosphorus concentrations near the proposed dam site had median values of 4.5 and $0.13 \mathrm{mg} / \mathrm{L}$, respectively. Suspended sediment discharges average between 100 and 200 tons per day. Concentrations range from $3 \mathrm{mg} / \mathrm{L}$ to more than $500 \mathrm{mg} / \mathrm{L}$. Bed material samples contain trace quantities of aldrin, DDT, DDD, DDE, dieldrin, and chlordane. Polychlorinated biphyenyls (PCB's) ranged from 10 to $100 \mu \mathrm{g} / \mathrm{kg}$ Fecal Coliform bacteria exceeded the recommended standards in 29 percent of the monthly samples, and exceeded the recommended public bathing water standard in 83 percent of the samples collected from June to September. Arsenic from an industrial waste was found in the water, suspended sediment, and bed material of Tulpehocken Creek in concentrations of 0 to $30 \mu \mathrm{g} / 1,2$ to $879 \mu \mathrm{g} / 1$, and 1 to $79 \mu \mathrm{g} / \mathrm{g}$, respectively.

17. Key Words and Document Analysis. 17a. Descriptors

*Aquatic environment, *limnology, *water quality, *microbiology, arsenicals, stream pollution, *nutrients

17b. Identifiers/Open-Ended Terms

Delaware River Basin, Limnology Survey

17c. COSATI Field/Group

18. Availability Statement

NO RESTRICTION ON DISTRIBUTION

\begin{tabular}{|c|c|}
\hline $\begin{array}{l}\text { 19. Security Class (This } \\
\text { Report) } \\
\text { UNCLASSIEIED }\end{array}$ & $\begin{array}{l}\text { 21. No, of Pages } \\
67\end{array}$ \\
\hline $\begin{array}{l}\text { 20. Security Class (This } \\
\text { Page } \\
\text { UNCLASSIFIED }\end{array}$ & 22. Price \\
\hline
\end{tabular}


WATER-QUALITY STUDY OF TULPEHOCKEN CREEK,

BERKS COUNTY, PENNSYLVANIA, PRIOR TO

IMPOUNDMENT OF BLUE MARSH LAKE

James L. Barker

U.S. GEOLOGICAL SURVEY

Water-Resources Investigations 77-55

U. S. GEOLOGICAL SURVEY WATER RESOURCES DIVISION PENNSYLVANIA DISTRICT

Prepared in cooperation with the

U.S. Army Corps of Engineers,

Philadelphia District

September 1977 

UNITED STATES DEPARTMENT OF THE INTERIOR

CECIL D. ANDRUS, Secretary

GEOLOGICAL SURVEY

V. E. McKelvey, Director

For additional information write to:

U.S. Geological Survey

Fourth Floor, Federal Building

P. 0. Box 1107

Harrisburg, Pennsylvania 17108 

Factors for converting English units to International

System (SI) units -

Abstract -

Introduction -_-_-_-_-_-_- 2

Purpose and scope - 2

Description of area - 2

Climatology - 4

Hydrology -

Methods of investigation -_- 8

Water-quality criteria - 11

General criteria -_-_-_-_- 11

Water-quality characteristics - 11

Historical water quality 11

Physical and chemical - 20

Temperature --_-_- 20

pH --

Alkalinity -_-_-_-_-_-_-_- 20

Dissolved oxygen --_- 22

Specific conductance -

Nutrients and organic carbon - 28

Nitrogen and phosphorus - 28

Total organic carbon (TOC) - 28

Bacteria --

Sediment and bed material - 37

Soils -

Results and conclusions - 47

Selected references -- 58

\section{ILLUSTRATIONS}

Figure 1.--Map showing Blue Marsh Lake drainage basin ----- 3

2.--Graph showing average monthly temperature, precipitation, and runoff - 5

3.--Map showing distribution of average annual precipitation, 1930-64 --_-_-_-_-_-_-_-_ 6

4.--Map showing distribution of average annual runoff, 1940-64 --_- 
Figure 5.--Graph showing relation between discharge and theoretical retention time in Blue Marsh

Lake

6.--Map showing $\mathrm{pH}$ in the Tulpehocken Creek basin

7.--Map showing total alkalinity in the Tulpehocken Creek basin

8.--Graph showing relation between discharge and total alkalinity in the Tulpehocken Creek basin

9.--Map showing dissolved oxygen concentrations in the Tulpehocken Creek basin

10.--Map showing specific conductance in the Tulpehocken Creek basin

11.--Graph showing relation between discharge and specific conductance in the Tulpehocken Creek basin near Blue Marsh Lake basin

12.--Map showing nitrate-nitrogen concentrations in the Tulpehocken Creek basin -

13.--Map showing total phosphorus concentrations in Tulpehocken Creek basin

14.--Graph showing relation between discharge and total nitrogen in Tulpehocken Creek basin near Blue Marsh Dam site

15.--Graph showing relation between discharge and total phosphorus in Tulpehocken Creek basin near Blue Marsh Dam site

16.--Map showing concentrations of total organic carbon in Tulpehocken Creek basin

17.--Map showing concentrations of total coliform in Tulpehocken Creek basin -

18.--Map showing concentrations of fecal coliform in Tulpehocken Creek basin -

19.--Map showing concentrations of fecal streptococci in Tulpehocken Creek basin --_-_-_-_-_-_-_--

20.--Graph showing daily sediment transport curve (1973) for Tulpehocken Creek basin near Blue Marsh Dam site -

21.--Graph showing relation between suspendedsediment concentration and arsenic concentration in Tulpehocken Creek near Blue Marsh Dam site

22.--Graph showing relation between arsenic load and discharge in Tulpehocken Creek basin near Blue Marsh Dam site 
Page

Table 1.--Magnitude and frequency of annual low flow

2.--Monthly variation of daily discharge for Tulpehocken Creek at Blue Marsh Dam site near Reading, $\mathrm{Pa} ., 1952-64$

3.--Water-quality criteria for waters of Tulpehocken $\begin{array}{ll}\text { Creek from the headwaters to Blue Marsh Lake - } & 12\end{array}$

4.--Water-quality criteria for Blue Marsh Lake --_-_-_- 13

5.--Summary of historical water-quality data, 1947-65, Tulpehocken Creek near Reading, Pa. - 14

6.--Water-quality data summary for Tulpehocken Creek basin, June 24-25, 1968 -_- 16

7.--Particle-size and nutrient content of bed material in Tulpehocken Creek - 40

8.--Concentrations of selected elements in bed material in Tulpehocken Creek

9.--Insecticide analyses of bed materia.t collected October 17,1972

10.--Physical and chemical analyses of soils in the Tulpehocken Creek flood plain, June 13, 1973

11.--Suspended-sediment and arsenic concentration in Tulpehocken Creek at Blue Marsh Dam site near Reading, $\mathrm{Pa}$.

FACTORS FOR CONVERTING ENGLISH UNITS TO INTERNATIONAL SYSTEM (SI) UNITS

\section{Multiply English units}

inches (in)

feet ( $\mathrm{ft}$ )

miles (mi)

acres

square miles $\left(\mathrm{mi}^{2}\right)$

acre-feet (acre-ft)

cubic feet per second $\left(\mathrm{ft}^{3} / \mathrm{s}\right)$

pounds per acre ( $1 \mathrm{~b} / \mathrm{acre}$ )

tons (short)
$\underline{B y}$

$$
\begin{array}{rl}
25 & .4 \\
& \cdot 3048 \\
1 & .609 \\
4.047 & \times 10^{-3} \\
2 & .590 \\
1.233 & .10^{-6} \\
.02832 \\
1.1208
\end{array}
$$

.9072
To obtain SI units

millimeters (mm)

meters (m)

kilometers $(\mathrm{km})$

square kilometers $\left(\mathrm{km}^{2}\right)$

square kilometers $\left(\mathrm{km}^{2}\right)$

cubic kilometers $\left(\mathrm{km}^{3}\right)$

cubic meters per second $\left(\mathrm{m}^{3} / \mathrm{s}\right)$

kilograms per square hetometer

$\left(\mathrm{kg} / \mathrm{hm}^{2}\right)$

metric tons ( $t$ ) 



\title{
WATER-QUALITY STUDY OF TULPEHOCKEN CREEK, BERKS COUNTY, PENNSYLVANIA, PRIOR TO IMPOUNDMENT OF BLUE MARSH LAKE
}

\author{
By James L. Barker
}

\section{ABSTRACT}

Blue Marsh Lake is planned as a multipurpose impoundment to be constructed on Tulpehocken Creek near Bernville, Berks County, Pennsylvania. Prior to construction, samples of water, bed materia1, and soil were collected through-out the impoundment site to determine concentrations of nutrients, insecticides, trace metals, suspended sediment, and bacteria.

Analyses of water suggest the Tulpehocken Creek basin to be a highly fertile environment. Nitrogen and phosphorus concentrations near the proposed dam site had median values of 4.5 and $0.13 \mathrm{mg} / \mathrm{L}$, respectively.

Suspended sediment discharges average between 100 and 200 tons (90.7 to 181.4 metric tons) per day during normal flows but may exceed 10,000 tons (9,070 metric tons) per day during storm runoff. Highest yields were measured during winter and early spring. Concentrations range from $3 \mathrm{mg} / \mathrm{L}$ to more than $500 \mathrm{mg} / \mathrm{L}$.

Bed material samples contain trace quantities of aldrin, DDT, DDD, $\mathrm{DDE}$, dieldrin, and chlordane. Polychlorinated biphyenyls (PCB's) ranged from 10 to $100 \mu \mathrm{g} / \mathrm{kg}$.

Soils at the impoundment site are of average fertility. However, the silt loam texture is ideal for attachment and growth of aquatic plants. 
Bacteria populations indicative of recent fecal contamination are prevelent in the major inflows to the proposed lake. Fecal Coliform exceeded the standards recommended by the Federal Water Pollution Administration Committee on Water Quality Criteria for public water supply in 29 percent of the monthly samples, and exceeded the recommended public bathing waters standard in 83 percent of the samples collected from June to September.

Arsenic from an industrial waste was found in the water, suspended sediment, and bed material of Tulpehocken Creek in concentrations of 0 to $30 \mu \mathrm{g} / 1,2$ to $879 \mu \mathrm{g} / 1$, and 1 to $79 \mu \mathrm{g} / \mathrm{g}$, respectively. It represents a potential environmental hazard; however, the measured concentrations are less than that known to be harmful to man, fish, or wildlife, according to published water quality criteria.

\section{INTRODUCTION}

\section{Purpose and Scope}

The preimpoundment investigation of water quality in the Tulpehocken Creek basin was begun at the request of the U.S. Army Corps of Engineers. The purpose of this investigation was to collect base-line water-quality data for Tulpehocken Creek and its major tributaries in the vicinity of the proposed Blue Marsh Lake site.

This report is limited to the presentation and discussion of chemical, physical, and bacteriological data collected within Tulpehocken Creek basin before April 1975. Data include: (1) the type and distribution of nutrients, (2) the variability and trends in nutrient loads, (3) soil characteristics of the lake site, (4) sedimentation characteristics, (5) bacteriological quality and trends, (6) metal analyses of sediment and water, and (7) insecticide analyses of sediments. This report is intended to supplement a 1973 report published by the Corps, which included a comprehensive data evaluation of water-quality, arsenic contamination, mathematical modeling, and management objectives.

\section{Description of Area}

The proposed dam site is located on Tulpehocken Creek $5 \mathrm{mi}(8 \mathrm{~km})$ upstream from its confluence with the Schuylkill River near Reading. The lake formed by the dam will extend upstream to Bernville, about $8 \mathrm{mi}$ $(12.9 \mathrm{~km})$, and will inundate parts of two tributaries, about $1 \mathrm{mi}(1.6$ $\mathrm{km}$ ) of Licking Creek and $2.3 \mathrm{mi}(3.7 \mathrm{~km}$ ) of Spring Creek (fig. 1). The drainage includes $175 \mathrm{mi}^{2}\left(453 \mathrm{~km}^{2}\right)$ and is located within Berks and Lebanon Counties. The basin is predominantly agricultural but includes the villages of Wernersville, Robesonia, Womelsdorf, Mount Pleasant, and Bernville. 


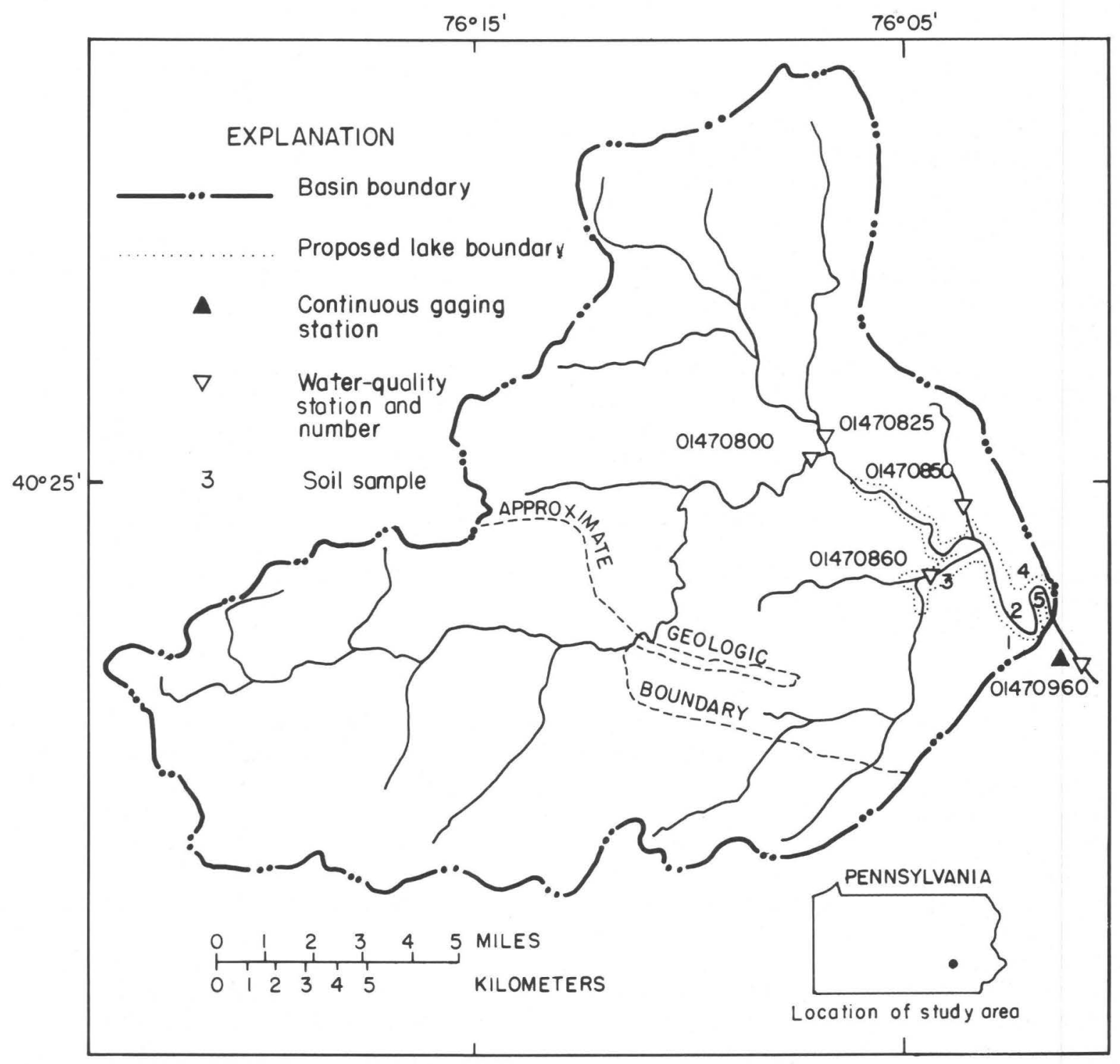

Figure 1.--Map showing Blue Marsh Lake drainage basin. 
Tulpehocken Creek drainage flows through a complicated sequence of rocks that have been extensively deformed by folds, faults, and possibly gravity slides in the Great Valley Section of the Appalachian Valley and Ridge Province. The northern two-thirds of the drainage area is underlain for the most part by the Martinsburg Formation of Middle and Late Ordovician age, the southern one-third by a belt of mostly Lower Ordovician carbonate rocks that have been divided into numerous formations. (See figure 1 for approximate geologic boundary.)

\section{Climatology}

The Tulpehocken Creek basin has rugged topography. This ruggedness causes greater temperature variations than that prevailing in the neighboring coastal plain or piedmont. Data collected at the Reading $3 \mathrm{~N}$ station of the U.S. Weather Bureau show that the monthly mean maximum temperature occurs in July and the minimum in January (fig. 2). The mean annual temperature is $53.7^{\circ} \mathrm{F}\left(12.0^{\circ} \mathrm{C}\right)$ and summer and winter averages are $72^{\circ} \mathrm{F}$ $\left(22.0^{\circ} \mathrm{C}\right)$ and $31^{\circ} \mathrm{F}\left(-0.5^{\circ} \mathrm{C}\right)$, respectively (Biesecker, and others, 1968).

Rainfall averages about 40 in $(1,016 \mathrm{~mm})$ per year or about the average for Pennsylvania as a whole (fig. 3). Precipitation is fairly evenly distributed throughout the year (fig. 2) but is somewhat higher during the summer.

\section{Hydrology}

Runoff depends in part upon the precipitation that an area receives and upon the physical characteristics of the basin, such as slope and vegetal cover. The annual distribution of runoff for Tulpehocken Creek basin is shown in figure 4. Maximum runoff normally occurs in early spring or late winter before emergence of heavy vegetal cover, whereas, minimum runoff occurs in late summer or early autumn. About 19.63 in $(499 \mathrm{~mm})$ of precipitation, or 48 percent, reaches the stream as runoff.

The stream channel within the impoundment site has a slope of 6.4 $\mathrm{ft} / \mathrm{mi}(1.2 \mathrm{~m} / \mathrm{km})$. Streamflow data were collected at partial-record stations established at four sampling sites and at a U.S. Geological Survey gaging station (01470960) near the Blue Marsh Dam site. The record at the Blue Marsh Dam site station shows the average annual discharge from May 1965 through September 1973 to be $253 \mathrm{ft}^{3} / \mathrm{s}\left(7.16 \mathrm{~m}^{3} / \mathrm{s}\right)$ or 19.63 in $(49 \mathrm{~mm})$. The maximum recorded discharge was $16,100 \mathrm{ft}^{3} / \mathrm{s}\left(456 \mathrm{~m}^{3} / \mathrm{s}\right)$ on June 22, 1972, and the minimum discharge was $22 \mathrm{ft}^{3} / \mathrm{s}(0.62 \mathrm{~m} / \mathrm{s})$ on September 11-13, 1966. 

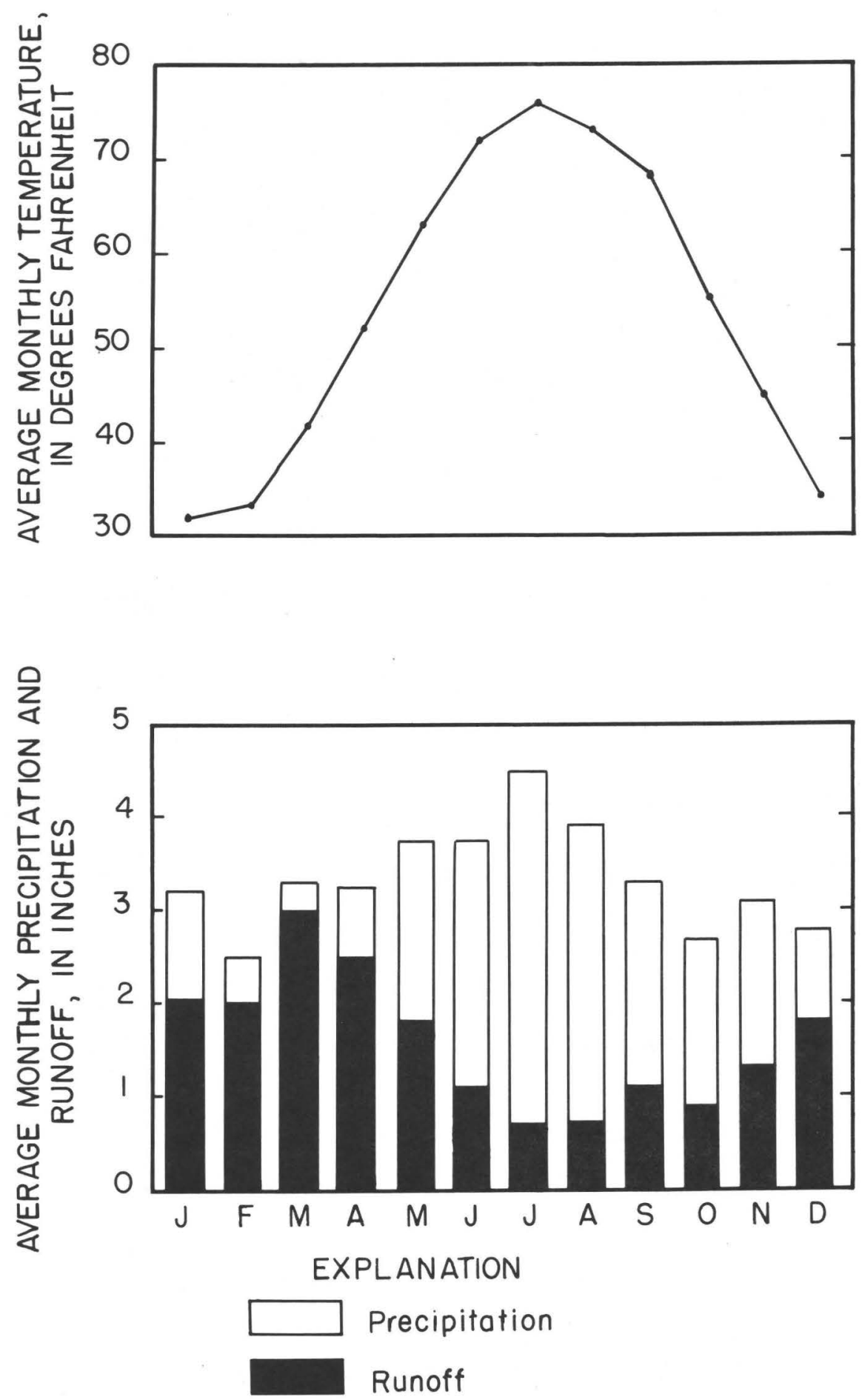

Figure 2.--Graph showing average monthly temperature, precipitation, and munoff. 


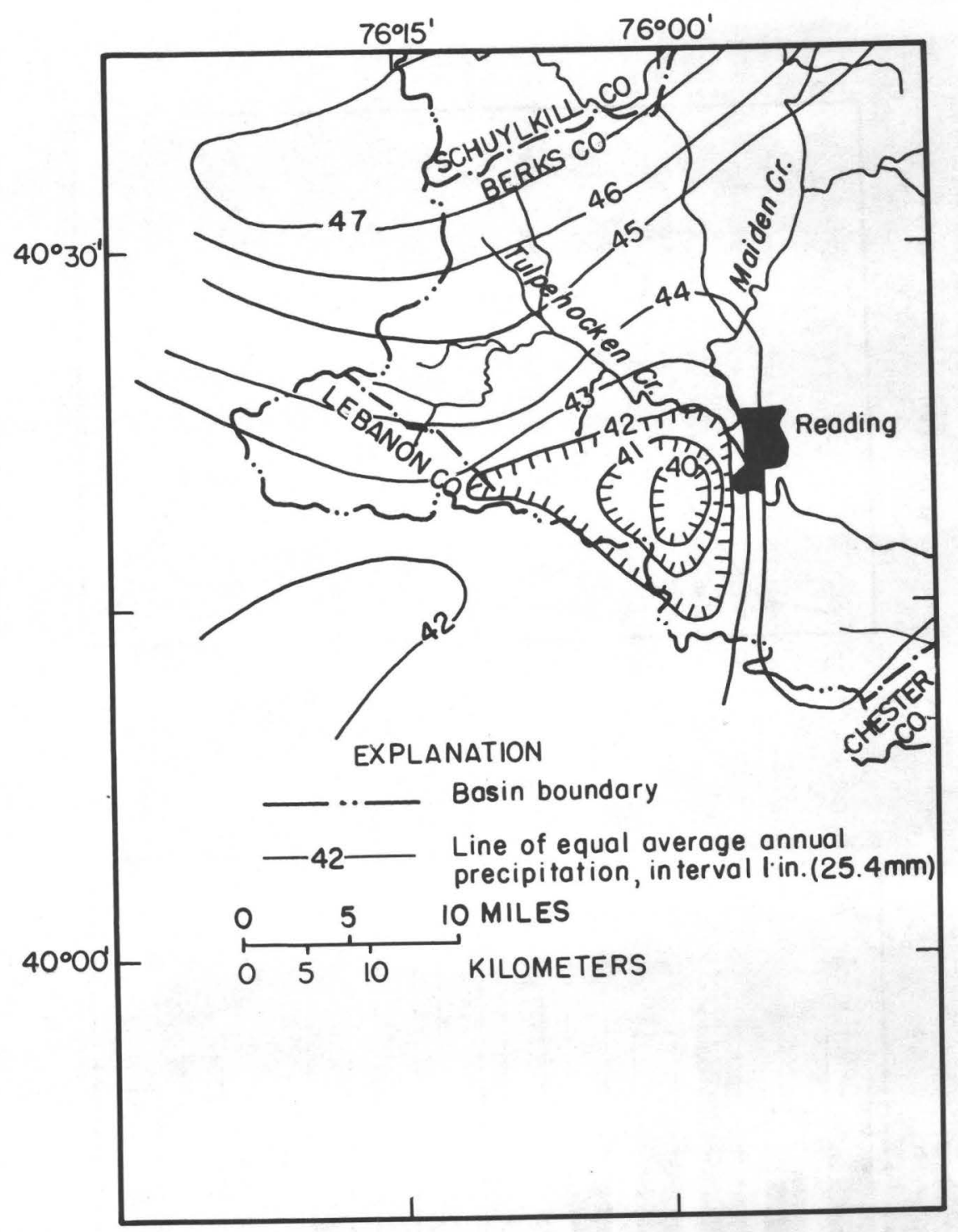

Figure 3.--Map showing distribution of average annual precipitation, 1930-64.

Tables 1 and 2 present low-flow frequency and monthly variation of daily discharge for Tulpehocken Creek at Blue Marsh Dam site near Reading. Table 1 is a tabulation of the minimum discharge that may be expected for selected recurrence intervals and number of consecutive days. The monthly variation (table 2) in streamflow is shown as the percentage of time that a given discharge was equaled or exceeded for each month. 


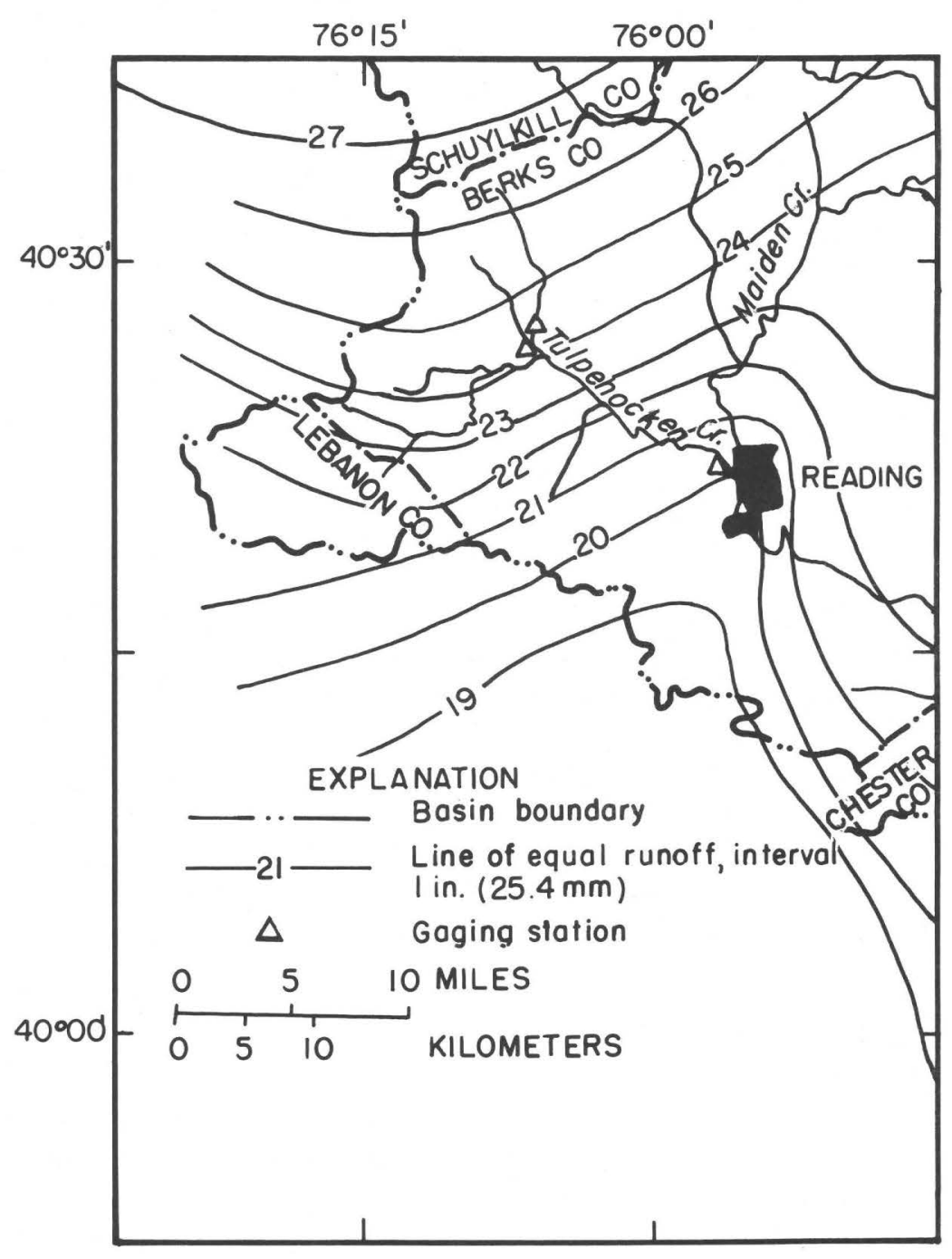

Figure 4.--Map showing distribution of average annual runoff, 1940-64.

Retention time or time-of-travel of solutes can be important in the eutrophication of impoundments as well as to the users of water downstream from an impoundment. Based on the mean runoff for the $175 \mathrm{mi}^{2}\left(453 \mathrm{~km}^{2}\right)$ basin and the capacity of the lake at normal pool elevation, the theoretical retention time or time for total exchange of the water is 25 days. Actual time will range from 125 days at low flow $\left(50 \mathrm{ft}^{3} / \mathrm{s}\right.$ or $\left.1.4 \mathrm{~m} 3 / \mathrm{s}\right)$ to less than 1 day during floods (fig. 5). The theoretical retention time assumes complete mixing and a volume-for-volume displacement. 
Table 1.--Magnitude and frequency of annual Zow flow. 1 I

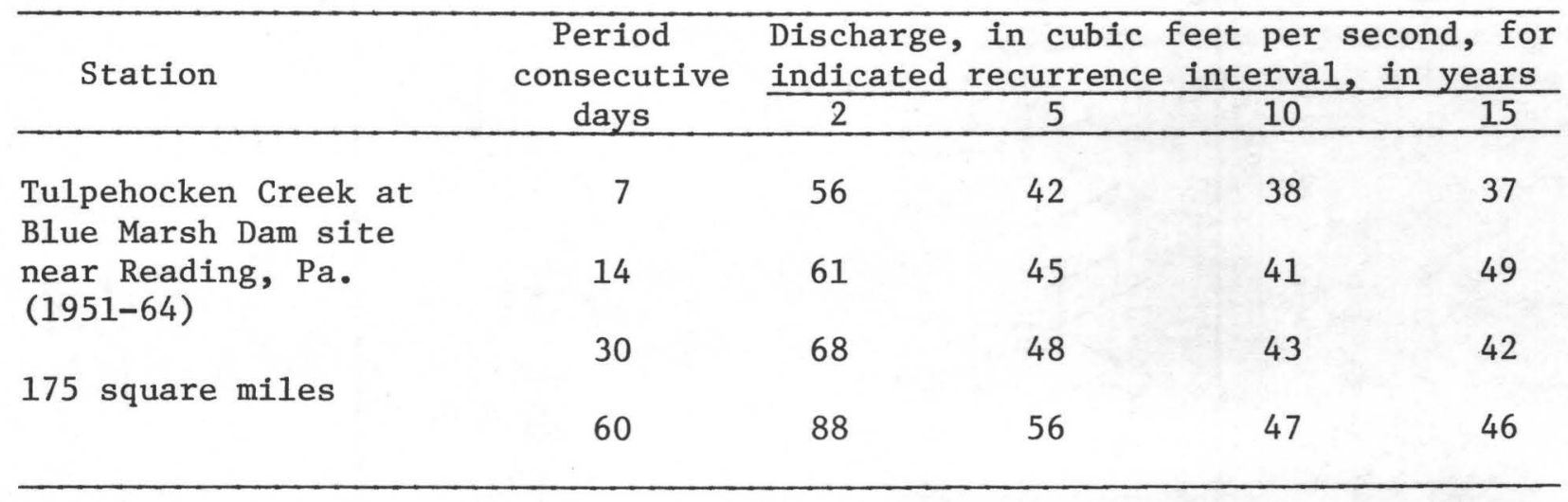

1/ Flow adjusted to low flow discharges at Tulpehocken Creek near Reading, Pa.

\section{METHODS OF INVESTIGATION}

The sites at which samples of surface water and bed material were taken were selected to characterize the primary inflows and outflows of the lake area. Soil samples were selected to define the effect of various land uses on the flood plain. The locations of the sampling sites are illustrated in figure 1. U.S. Geological Survey station numbers and locations of the sampling sites and gaging stations are listed below:

Station number

01470800

01470825

01470850

01470860

01470960

01471000

\section{Location}

Tulpehocken Creek at Legislative Route 06047 bridge at Bernville

Northki11 Creek at retaining wall along left bank of creek, $670 \mathrm{ft}$ (204 m) upstream from Legislative Route 06047 at Bernville

Licking Creek at steel culvert on Davis Bridge Road, $0.6 \mathrm{mi}(0.96 \mathrm{~km})$ north of State Highway 183 on Snyder School Road

Spring Creek at Peacock Bridge near Bernville

Tulpehocken Creek at Blue Marsh dam site near Reading Tulpehocken Creek near Reading 
Table 2.--Monthly variation of daily discharge for Tulpehocken Creek at Blue Marsh Dam site near Reading, Pa., 1952-64.1/

[Discharge, in cubic feet per second]

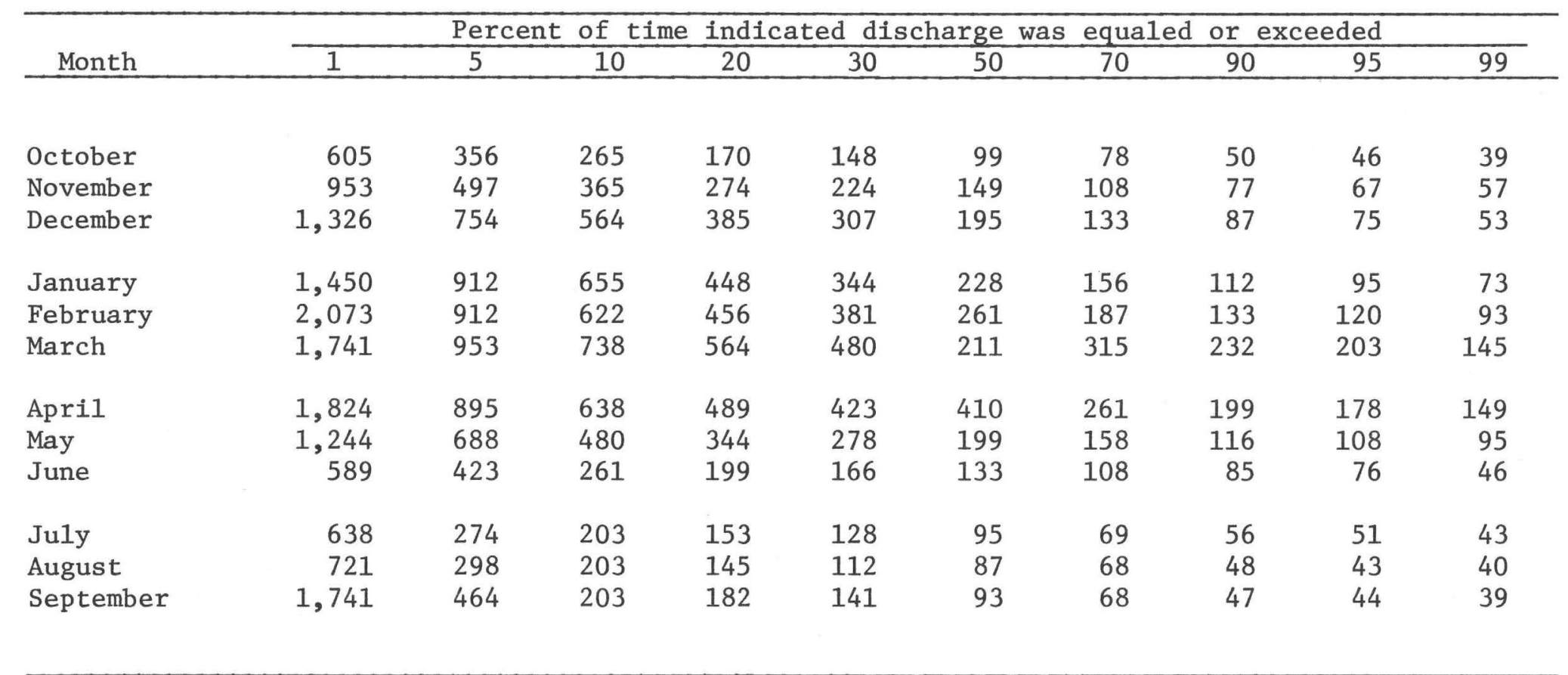

1/ Flow adjusted to low flow discharges at Tulpehocken Creek near Reading, Pa. 


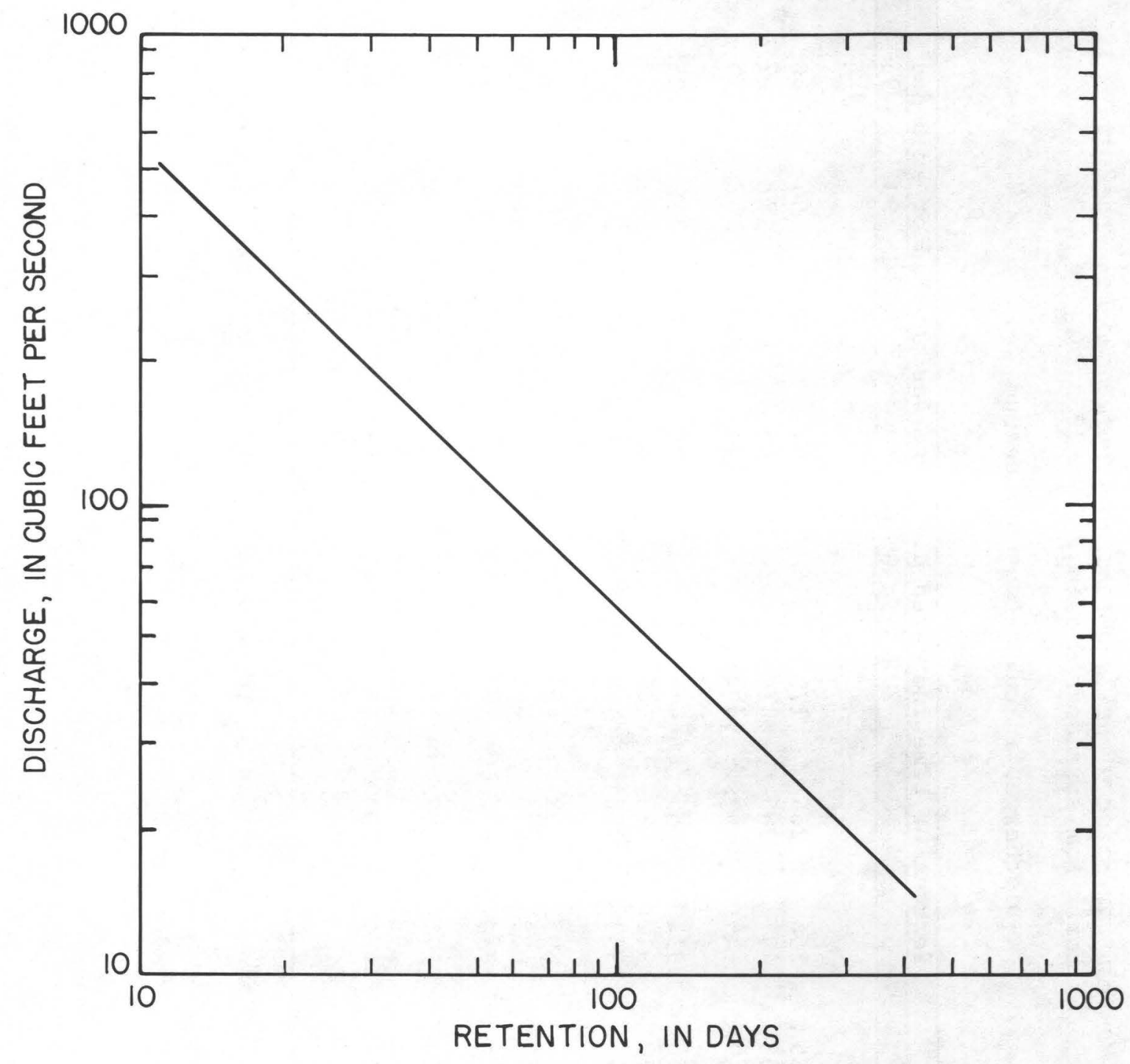

Figure 5.--Graph showing relation between discharge and theoretical retention time in Blue Marsh Lake. 
The water sampling began on June 14, 1972, and is continuing at monthly intervals (plus additional samples during selected storms). Initially, five sites were sampled, but the number was reduced to four sites in May 1973 and then to three sites in July 1973. Whole water samples are analyzed for nitrate-nitrogen, organic nitrogen, ammonia nitrogen, total and ortho-phosphorus, and total organic carbon。 Additional samples are analyzed for total and fecal coliform and fecal streptococci bacteria densities. Dissolved oxygen, temperature, $\mathrm{pH}$, and specific conductance are determined at the time of collection.

Daily sampling of suspended-sediment began on May 20, 1973. An additional sample was collected for arsenic analysis, when the sediment concentration was visibly heavy. As of April 1975, 83 samples had been analyzed for arsenic. Samples of bed material were collected annually and analyzed for insecticides, trace metals, and particle size.

A11 sampling and analyses were conducted according to methods prescribed by Brown and others (1970), Slack and others (1973), Georlitz and Brown (1972), and Guy (1969). Samples were analyzed at U.S. Geological Survey laboratories.

\section{WATER QUALITY CRITERIA}

The Pennsylvania Sanitary Water Board (1967) developed water-quality criteria specifically for Tulpehocken Creek, from its headwaters to Blue Marsh Lake and for Blue Marsh Lake (tables 3 and 4).

\section{Genera1 Criteria}

According to the Pennsylvania Sanitary Water Board, (1967), the water shall not contain substances attributable to municipal, industrial, or other waste discharges in concentrations or amounts sufficient to be inimical or harmful to water uses to be protected or to human, animal, plant, or aquatic life. Specific substances to be controlled include, but are not limited to, floating debris, oil, scum, and other floating materials; toxic substances; substances that produce color, taste, odors or settle to form sludge.

\section{WATER QUALITY CHARACTERISTICS}

\section{Historica1 Water Quality}

Water samples were collected for chemical analyses on Tulpehocken Creek at the gaging station near Reading from 1947 to 1965 (table 5). In June 1968, the Federal Water Pollution Control Administration made a chemical and biological reconnaissance at 15 sampling sites throughout the Tulpehocken basin. Results of these analyses are presented in table 6 . 
Table 3.--Water quality criteria for waters of Tulpehocken Creek from the headwaters to Blue Marsh Lake. II

[Pennsylvania Sanitary Water Board, 1967]

\section{Criteria}

$\mathrm{pH}$

Dissolved oxygen

Total iron

Temperature

Dissolved solids

Bacteria

(coliforms/100 mL)

Dissolved phosphate
Not less than 6.0 ; no more than 8.5 .

Minimum daily average $6.0 \mathrm{mg} / \mathrm{L}$; no value less than $5.0 \mathrm{mg} / \mathrm{L}$.

Not to exceed $1.5 \mathrm{mg} / \mathrm{L}$.

Not to exceed $58^{\circ} \mathrm{F}\left(14.4^{\circ} \mathrm{C}\right)$ for natural temperature, whichever is greater.

Not to exceed $500 \mathrm{mg} / \mathrm{L}$ as a monthly average value; not to exceed $750 \mathrm{mg} / \mathrm{L}$ at any time.

For the period May 15 - September 15 of any year, not to exceed $1,00 / 100 \mathrm{~mL}$ as an arithmetic-average value; not to exceed $1,000 / 100 \mathrm{~mL}$ in more than two consecutive samples; not to exceed $2,400 / 100 \mathrm{~mL}$ in more than one sample.

For the period September 16 - May 14 of the following year; not to exceed $5,000 / 100 \mathrm{~mL}$ as a monthly average value, nor to exceed this number in more than 20 percent of the samples collected during any month; not to exceed $20,000 / 100 \mathrm{~mL}$ in more than 5 percent of the samples.

Not to exceed $0.10 \mathrm{mg} / \mathrm{L}$ as $\mathrm{PO}_{4}$.

1/ Water use: Cold water fishes; maintenance and propagation of the family Salmonidae; and fish food organisms. 
Table 4.--Water quality criteria for Blue Marsh Lake.

[Pennsylvania Sanitary Water Board, 1967]

\section{Criteria}

$\mathrm{pH}$

Dissolved oxygen

Total iron

Temperature

Dissolved solids

Bacteria

Dissolved phosphate
Not less than 6.0 ; no more than 8.5 .

For lakes, ponds and impoundments on1y; no values less than $4.0 \mathrm{mg} / \mathrm{L}$ in the epilimnion.

Not to exceed $1.5 \mathrm{mg} / \mathrm{L}$.

Not to exceed $5^{\circ} \mathrm{F}\left(2.8^{\circ} \mathrm{C}\right)$ rise above ambient temperature or a maximum of $87^{\circ} \mathrm{F}\left(30.6^{\circ} \mathrm{C}\right)$, whichever is less; not to be changed by more than $2^{\circ} \mathrm{F}\left(1.1^{\circ} \mathrm{C}\right)$ during any one hour period.

Not to exceed $500 \mathrm{mg} / \mathrm{L}$ as a monthly average value; not to exceed $750 \mathrm{mg} / \mathrm{L}$ at any time.

For the period May 15 - September 15 of any year; not to exceed $1,000 / 100 \mathrm{~mL}$ as an arithmeticaverage vlaue; not to exceed $1,000 / 100 \mathrm{~mL}$ in more than two consecutive samples; not to exceed $2,400 / 100 \mathrm{~mL}$ in more than one sample.

For the period September 16 - May 14 of the following year; not to exceed $5,000 / 100 \mathrm{~mL}$ as a monthly average value, nor to exceed this number in more than 20 percent of the samples collected during any month; not to exceed $20,000 / 100 \mathrm{~mL}$ in more than 5 percent of the samples.

Not to exceed $0.10 \mathrm{mg} / \mathrm{L}$ as $\mathrm{PO}_{4}$. 
Table 5.--Summary of historical water quality data [Chemical constituents reported
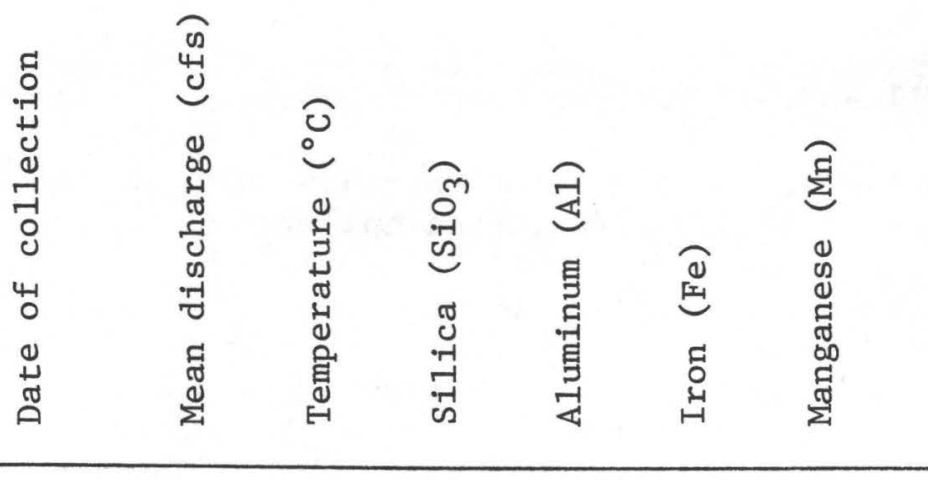

$\begin{array}{rrrrrrrrrrrr}9 / 10 / 47 & - & - & 7.2 & - & .69 & 0 & 50 & 13 & 3.0 & - & 170 \\ 10 / 15 / 57 & 58 & 13.9 & - & - & - & - & - & - & 5.5 & - & 172 \\ 4 / 22 / 59 & - & 11.7 & 4.5 & - & .23 & .01 & 40 & 9.4 & 5.0 & 2.3 & 126 \\ 10 / 22 / 59 & - & 10.6 & 5.6 & - & .15 & 0 & 50 & 14 & 6.0 & 3.0 & 174 \\ 4 / 27 / 60 & - & 17.2 & 4.5 & - & - & - & 43 & 13 & 4.0 & 2.4 & 148 \\ 6 / 20 / 61 & 147 & 20.0 & - & - & - & - & - & - & 6.7 & - & 174 \\ 10 / 17 / 62 & 119 & 18.9 & 3.9 & - & - & - & 42 & - & 7.6 & 3.2 & 152 \\ 10 / 04 / 63 & - & 16.1 & - & - & - & - & - & - & - & - & 184 \\ 10 / 18 / 63 & - & 16.1 & 2.0 & - & .12 & .01 & 50 & 14 & 8.6 & 3.6 & 188 \\ 4 / 01 / 64 & - & 5.0 & 8.5 & - & .12 & .0 & 40 & 8.8 & 5.5 & 1.2 & 124 \\ 9 / 15 / 64 & - & 16.1 & 4.7 & - & .09 & .0 & 50 & 18 & 8.5 & 3.7 & 196 \\ 7 / 01 / 65 & 53 & - & 1.9 & - & .22 & .07 & 34 & 18 & 8.7 & 3.2 & 146\end{array}$


1947-1965 Tulpehocken Creek near Reading, Pa. in milligrams per liter.]

\begin{tabular}{|c|c|c|c|c|c|c|c|c|c|c|}
\hline \multirow[b]{2}{*}{ 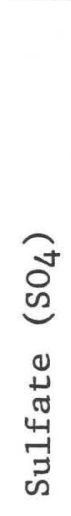 } & \multirow[b]{2}{*}{ 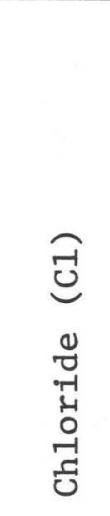 } & \multirow[b]{2}{*}{ 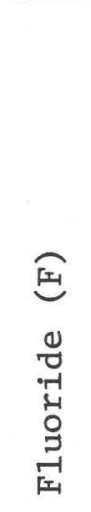 } & \multirow[b]{2}{*}{ 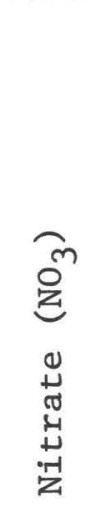 } & \multirow[b]{2}{*}{ 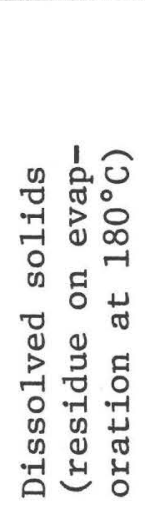 } & \multicolumn{2}{|c|}{$\begin{array}{l}\text { Hardness } \\
\text { as } \mathrm{CaCO}_{3}\end{array}$} & \multirow{2}{*}{ 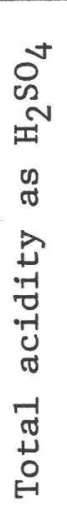 } & \multirow[b]{2}{*}{ 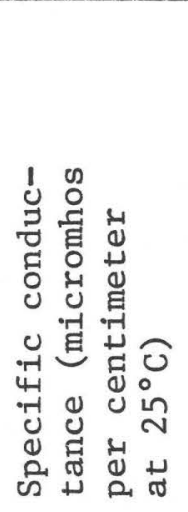 } & \multirow[b]{2}{*}{ 票 } & \multirow[b]{2}{*}{ 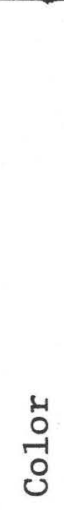 } \\
\hline & & & & & 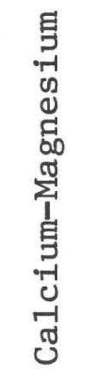 & 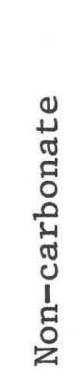 & & & & \\
\hline 26 & 4.8 & 0.1 & 3.2 & 209 & 178 & - & - & 348 & 7.7 & 4 \\
\hline 31 & 7.8 & - & 3.2 & - & - & - & - & 368 & 7.6 & 12 \\
\hline 26 & 4.5 & .2 & 2.0 & 182 & 139 & 35 & - & 280 & 7.5 & 3 \\
\hline 30 & 7.5 & .3 & 2.5 & 212 & 183 & 40 & - & 368 & 7.5 & 1 \\
\hline 26 & 6.4 & .1 & 2.5 & 209 & 161 & 40 & - & 324 & 7.7 & 3 \\
\hline 28 & 8.2 & - & 2.7 & 235 & 178 & 36 & - & 356 & 8.1 & 5 \\
\hline 27 & 9.8 & 0 & 1.8 & 205 & 163 & 38 & - & 339 & 8.2 & 10 \\
\hline 29 & 18 & - & 2.3 & - & 184 & 33 & - & 387 & 8.2 & 9 \\
\hline 28 & 11 & .1 & 2.3 & 236 & 183 & 29 & - & 389 & 7.7 & 4 \\
\hline 27 & 8.6 & .1 & 1.8 & 174 & 136 & 35 & - & 295 & 7.7 & 4 \\
\hline 33 & 13 & .0 & 2.7 & 251 & 199 & 39 & - & 413 & 7.6 & 3 \\
\hline 35 & 10 & .0 & 1.8 & 206 & 162 & 40 & - & 358 & 7.1 & 3 \\
\hline
\end{tabular}


Table 6.--Water quality data summary for Tulpehocken

[Chemical constituents reported

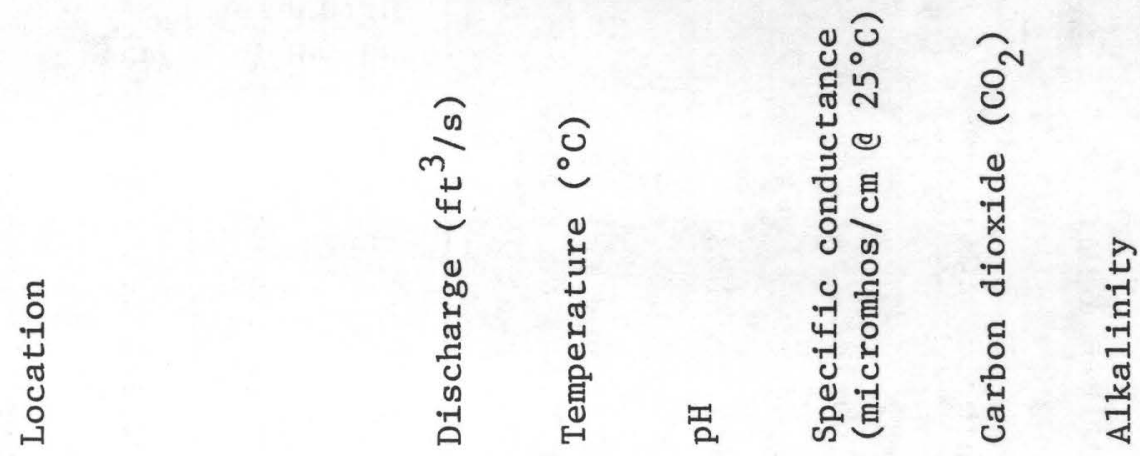

1 Tulpehocken Creek above Myerstown Waste Water Treatment Plant

$\begin{array}{llllll}12 & 16.6 & 8.1 & 537 & 3.4 & 181\end{array}$

2 Tulpehocken Creek below Myerstown Waste Water Treatment Plant

$\begin{array}{llllll}30 & 17.8 & 7.8 & 616 & 5.9 & 185\end{array}$

3 S. Mill Creek above confluence with Tulpehocken Creek

$\begin{array}{llllll}15 & 20.0 & 8.3 & 472 & 1.4 & 176\end{array}$

4 Tulpehocken Creek above Charming Forge

$\begin{array}{llllll}47 & 20.8 & 8.4 & 512 & 2.0 & 169\end{array}$

$\begin{array}{llllll}14 & 22.5 & 8.4 & 324 & 1.3 & 113\end{array}$ with Northkil1 Creek

6 Tulpehocken Creek above confluence with Northkill Creek

$\begin{array}{llllll}64 & 22.0 & 8.2 & 466 & 1.8 & 176\end{array}$

7 Little Northkill Creek above confluence with Northkill Creek

8 Northkill Creek above confluence with Little Northkill

$\begin{array}{llllll}13 & 24.8 & 8.6 & 115 & 0.0 & 35\end{array}$ Creek

$\begin{array}{llllll}14 & 25.7 & 9.0 & 179 & 0.0 & 51\end{array}$ 
Creek basin, date of collection June 24, 25, 1968.1/ in milligrans per liter.]

\begin{tabular}{|c|c|c|c|c|c|c|c|c|c|}
\hline 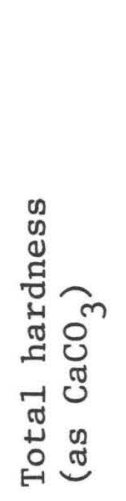 & 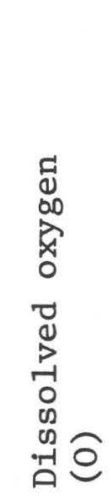 & 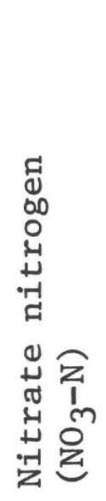 & 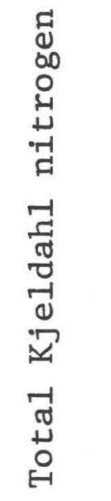 & 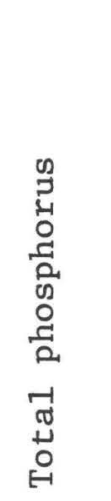 & 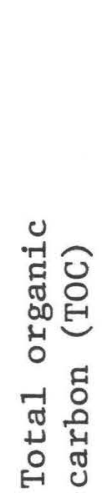 & 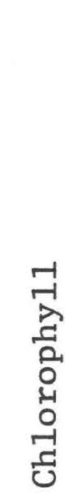 & 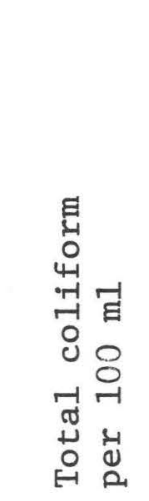 & 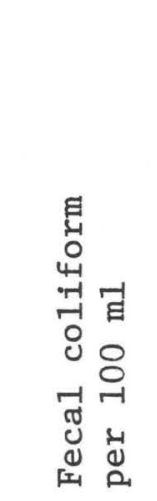 & 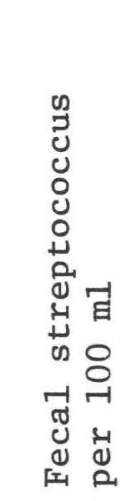 \\
\hline 242 & 10.4 & 5.2 & 0.56 & 0.13 & 7.2 & 2.4 & 3,850 & 2,020 & 1,050 \\
\hline 249 & 9.5 & 5.0 & 0.94 & 1.00 & 8.8 & 4.6 & 20,000 & 12,400 & 3,670 \\
\hline 235 & 10.3 & 4.6 & 1.16 & 0.28 & 7.5 & 7.9 & 11,700 & 10,000 & 1,450 \\
\hline 241 & 10.9 & 5.0 & 0.76 & 0.54 & 9.0 & 6.0 & 5,900 & 3,200 & 800 \\
\hline 151 & 10.6 & 3.3 & 0.56 & 0.18 & 8.0 & 2.2 & 5,400 & 3,700 & 1,400 \\
\hline 231 & 9.2 & 4.7 & 0.67 & 0.37 & 9.0 & 5.0 & 4,300 & 2,400 & 810 \\
\hline 73 & 10.2 & 1.8 & 0.66 & 0.21 & 5.0 & 5.8 & 4,300 & 2,600 & 1,300 \\
\hline 50 & 10.6 & 0.8 & 0.56 & 0.14 & 4.2 & 2.6 & 4,800 & 2,400 & \\
\hline
\end{tabular}


Table 6.--Water quality data summary for Tulpehocken Creek

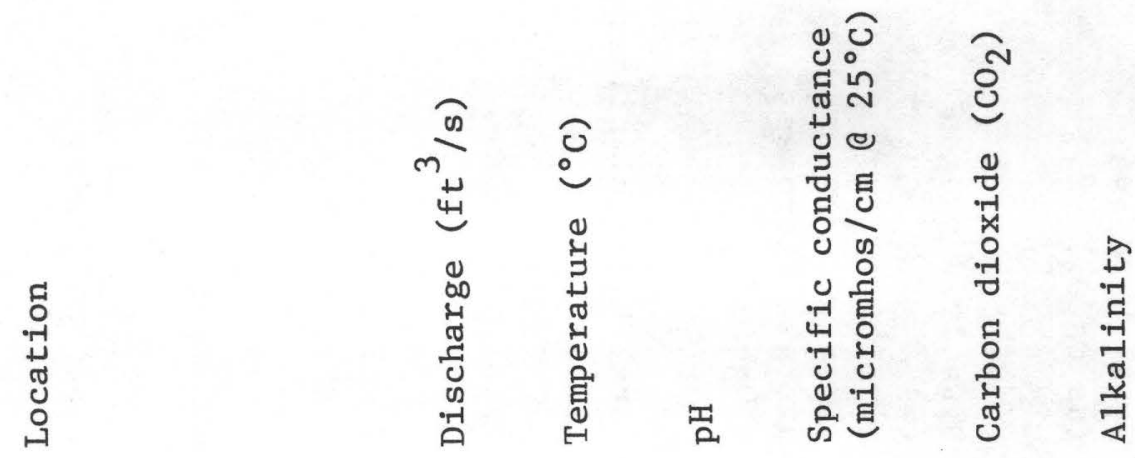

9 Northkill Creek above confluence 26
with Tulpehocken Creek

$\begin{array}{llllll}26 & 24.2 & 8.7 & 158 & 0.6 & 46\end{array}$

10 Manor Creek above Wernersville

$\begin{array}{llllll}6.7 & 17.7 & 7.7 & 300 & 5.0 & 101\end{array}$

State Hospital

11 Manor Creek below Wernersville

7.218.

State Hospital

12 Spring Creek above RobesoniaWernersville M. A.

$\begin{array}{llllll}18 & 16.4 & 7.9 & 301 & 4.0 & 97\end{array}$

13 Spring Creek below RobesoniaWernersville M. A.

$\begin{array}{llllll}19 & 16.6 & 7.8 & 301 & 3.4 & 98\end{array}$

14 Spring Creek above confluence with Tulpehocken Creek

$\begin{array}{llllll}21 & 17.8 & 7.7 & 307 & 5.1 & 101\end{array}$

15 Tulpehocken Creek near Dam site $\begin{array}{lllllll}125 & 20.7 & 7.4 & 367 & 3.7 & 138\end{array}$

$\begin{array}{lllllll}\text { Basin Average } & 29 & 20.0 & 8.1 & 350 & 2.9 & 117\end{array}$

1/ Four-sample average for each station except where noted.

2/ One sample. 
basin, date of collection June 24, 25, 1968.--continued.

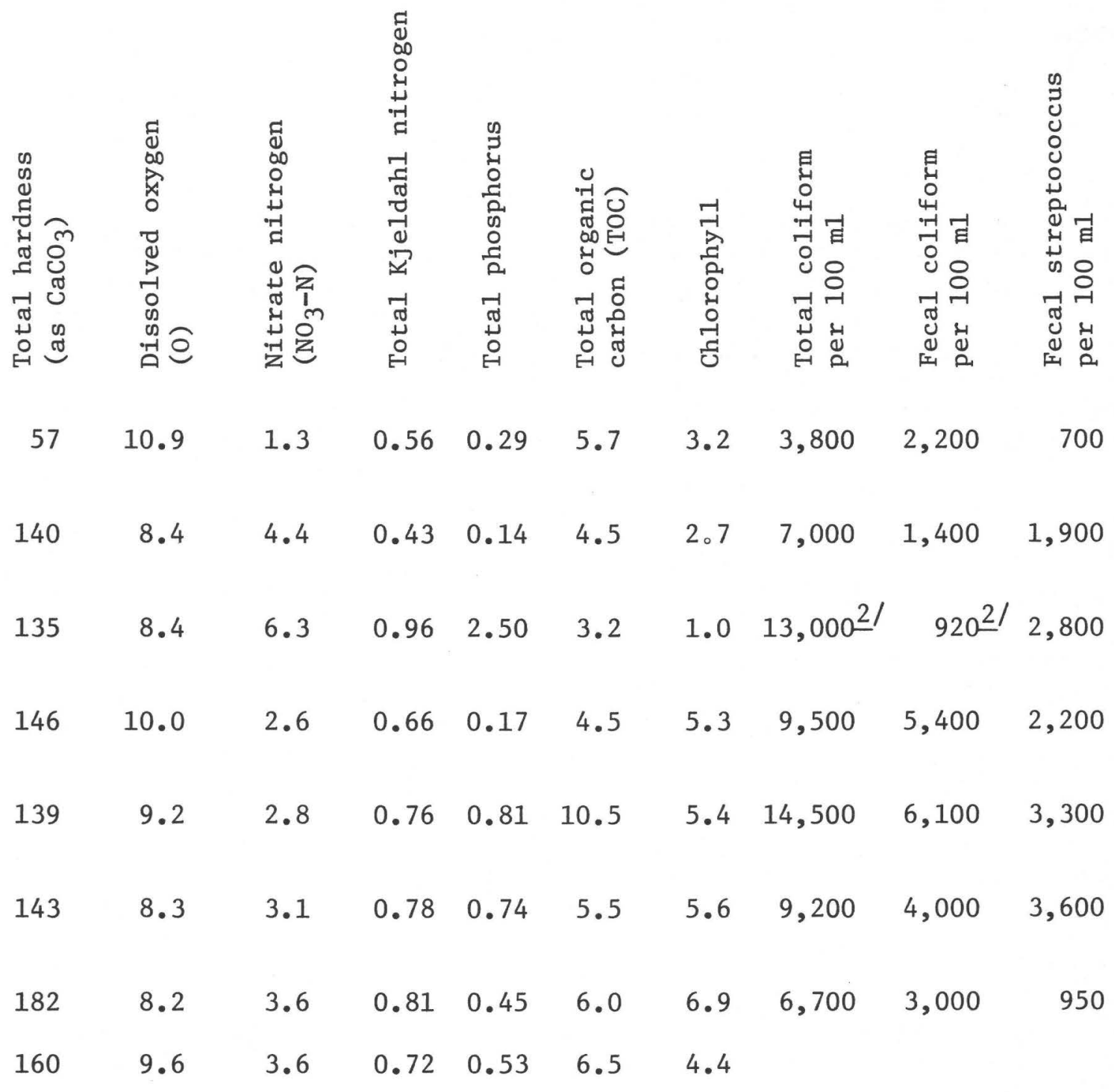


The median nitrate-nitrogen concentration near Reading of 12 analyses made between 1947 to 1965 was $2.3 \mathrm{mg} / \mathrm{L}$; whereas, the median concentration 5 miles upstream near Blue Marsh Dam site of 40 analyses made between 1972 to 1975 was $4.5 \mathrm{mg} / \mathrm{L}$. Nineteen water samples collected by the Pennsylvania Department of Environmental Resources at Tulpehocken Creek near Reading from 1972 to 1975 had a mean value of $4.5 \mathrm{mg} / \mathrm{L}$. These analyses indicate that there has been a nearly twofold increase in the nitrate-nitrogen concentration in Tulpehocken Creek in the past 10 years.

\section{Physical and Chemical}

\section{Temperature}

Water temperatures of Tulpehocken Creek during the present study ranged from $32^{\circ}$ to $75^{\circ} \mathrm{F}\left(0.0^{\circ}\right.$ to $\left.24.0^{\circ} \mathrm{C}\right)$. At all the sites the temperatures were less than the $86^{\circ} \mathrm{F}\left(30.0^{\circ} \mathrm{C}\right)$ maximum allowed by the Pennsylvania Sanitary Water Board's water-quality criteria. Maximum temperatures at Tulpehocken Creek near Bernville and Spring Creek seem to be due to some extent to warming by inflowing springs and possibly sewage-plant effluent. Water temperatures were found to be favorable to the development of a warm-water fishery and to all other intended reservoir uses.

$$
\mathrm{pH}
$$

The $\mathrm{pH}$ range for the maintenance of good game fish production should be between 6.5 and 8.5 (Cooper, 1967). The State pH standards of 6.0 to 8.5 are being met at all stations, with the exception of that at Tulpehocken Creek near Blue Marsh Dam site, which had a $\mathrm{pH}$ of 8.7 during a period of high photosynthetic activity (fig. 6).

Bicarbonate derived from limestone of the upper Tulpehocken and Spring Creek basin is responsible for a high buffering capacity of the water and for maintaining a pH on the main stem generally between 7.5 and 8.5. Northkill and Licking Creeks, which flow over shale of the Martinsburg Formation, have a lower buffering capacity and a $\mathrm{pH}$ generally between 7 and 8.

\section{Alkalinity}

Alkalinity is a measure of a water's ability to neutralize acid and is due to the presence of carbonate and bicarbonate, and to a lesser extent hydroxides, borates, silicates, phosphates, and organic substances. It is commonly reported in milligrams per liter of $\mathrm{CaCO}_{3}$. The addition of municipal sewage and industrial wastes may increase alkalinity. Alkalinity in excess of $170 \mathrm{mg} / \mathrm{L}$ has been reported to be deleterious to stock and wildlife (McKee and Wolf, 1971). Of the waters that support good fish population, 5 percent have bicarbonate concentrations of less than $40 \mathrm{mg} / \mathrm{L}$, 50 percent less than $90 \mathrm{mg} / \mathrm{L}$, and 95 percent less than 180 $\mathrm{mg} / \mathrm{L}$ (McKee and Wolf, 1971). 


\section{EXPLANATION}

$\mathrm{PH}$ value

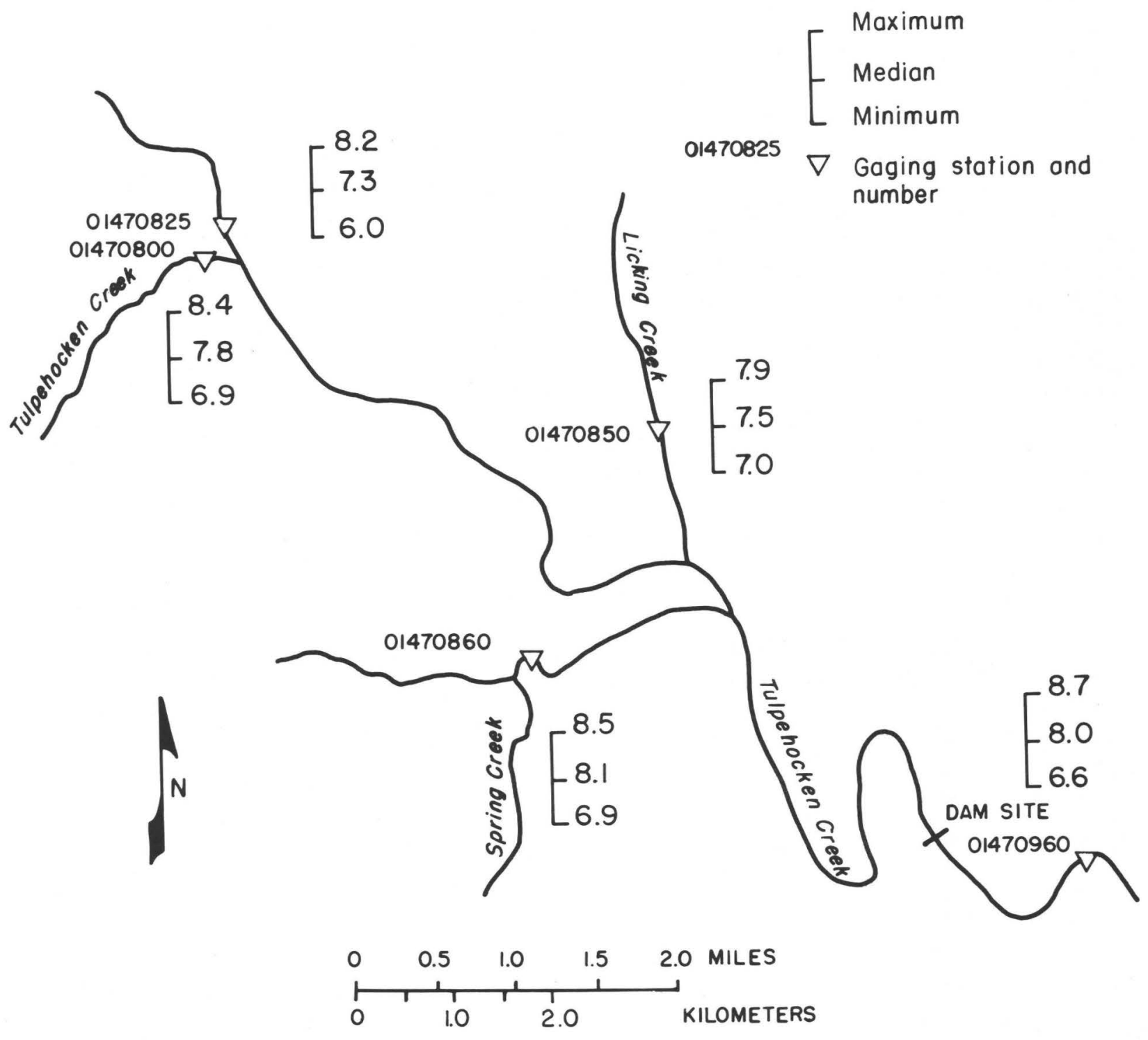

Figure 6.--Map showing $\mathrm{pH}$ in the Tulpehocken Creek basin. 
Water of the Tulpehocken basin, for the most part, has a total alkalinity equal to the bicarbonate alkalinity. Concentrations range from 62 to $254 \mathrm{mg} / \mathrm{L}$. Higher alkalinity is found in the main stem (fig. 7). The relation between total alkalinity and discharge (fig. 8) is inverse; alkalinity decreases as discharge increases.

\section{Dissolved Oxygen}

The concentration of dissolved oxygen in water in equilibrium with the atmosphere, depends on temperature and dissolved-solids content of the water. The solubility of dissolved oxygen increases as temperature and dissolved solids decrease. The State has established the minimum dissolved-oxygen concentration necessary for maintaining healthy aquatic life in Tulpehocken Creek as $5.0 \mathrm{mg} / \mathrm{L}$ and a daily mean not less than 6.0 $\mathrm{mg} / \mathrm{L}$ (table 3). Minimum values at all five stations (fig. 9) exceeded these standards, and although it is probable that the daylight sampling program has not disclosed the true minimum values, the criteria are undoubtedly met at all five sampling sites.

An analysis of the dissolved oxygen saturation curves for Tulpehocken Creek near Blue Marsh Dam site discloses that saturation was exceeded 87 percent of the time, indicating a high rate of photosynthesis of aquatic plants and a low biochemical oxygen demand (BOD).

\section{Specific Conductance}

Specific conductance is a measure of the ability of a unit volume of material to conduct electric current. In water, this ability is directly related to the concentration of ions and therefore to the concentration of dissolved solids. The following general relationship is applicable:

Specific conductance $\times 0.65 \pm=$ dissolved solids.

E11is' (1937) studies indicate that streams and rivers supporting good mixed fish fauna generally had a specific conductance between 150 to 500 micromhos per centimeter at $25^{\circ} \mathrm{C}$.

Water-quality criteria for Tulpehocken Creek (Pa. Sanitary Water Board, 1967) require that the monthly average must not exceed $500 \mathrm{mg} / \mathrm{L}$ dissolved solids and must not exceed $750 \mathrm{mg} / \mathrm{L}$ at any time. Specificconductance data indicate that these criteria are being met (fig. 10) at the dam site but were exceeded at Bernville on at least one occasion. As illustrated in figure 11 , specific conductance is inversely related to discharge; as flow increases, specific conductance decreases. 


\section{EXPLANATION}

Total alkalinity, in milligrams per liter
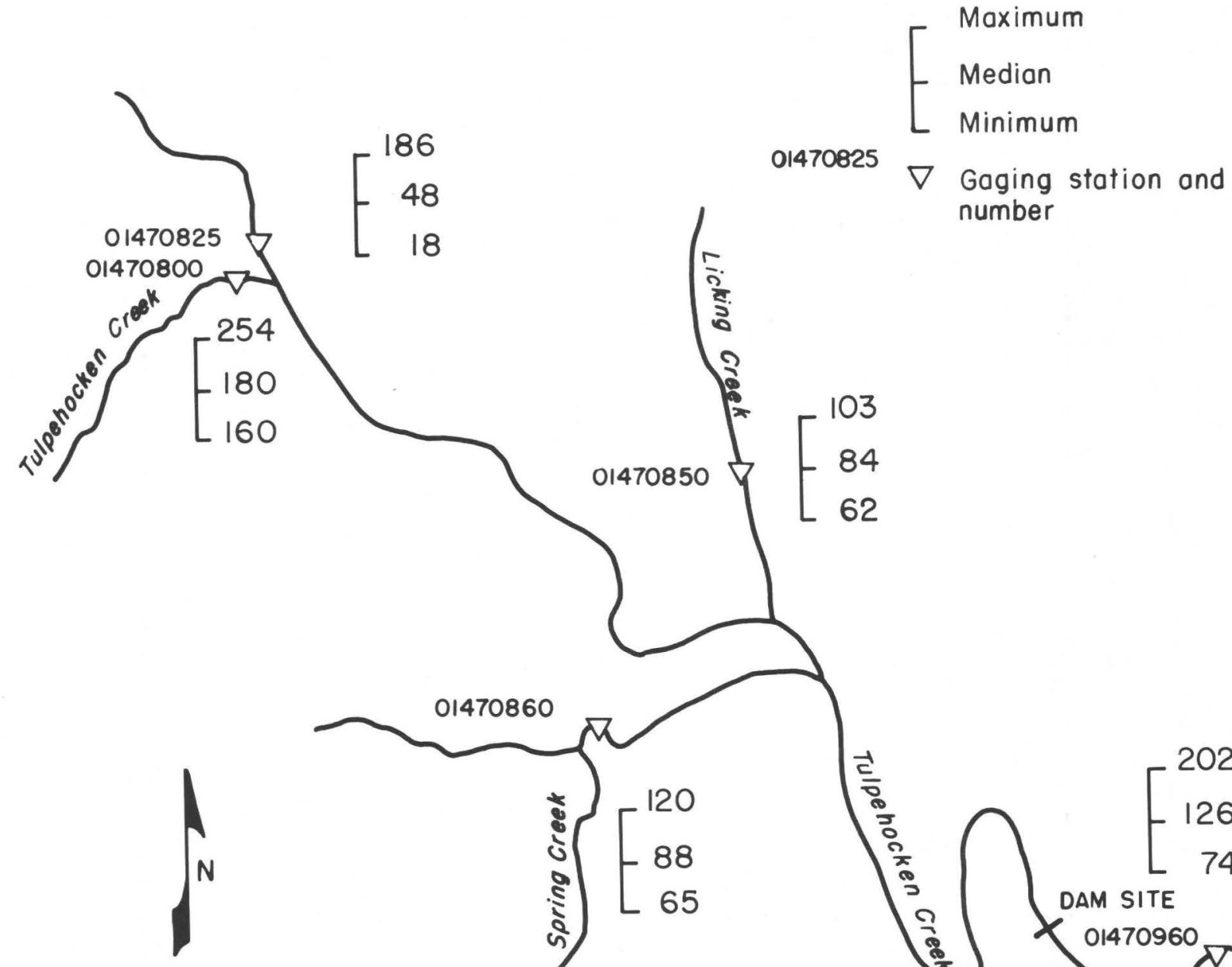
number

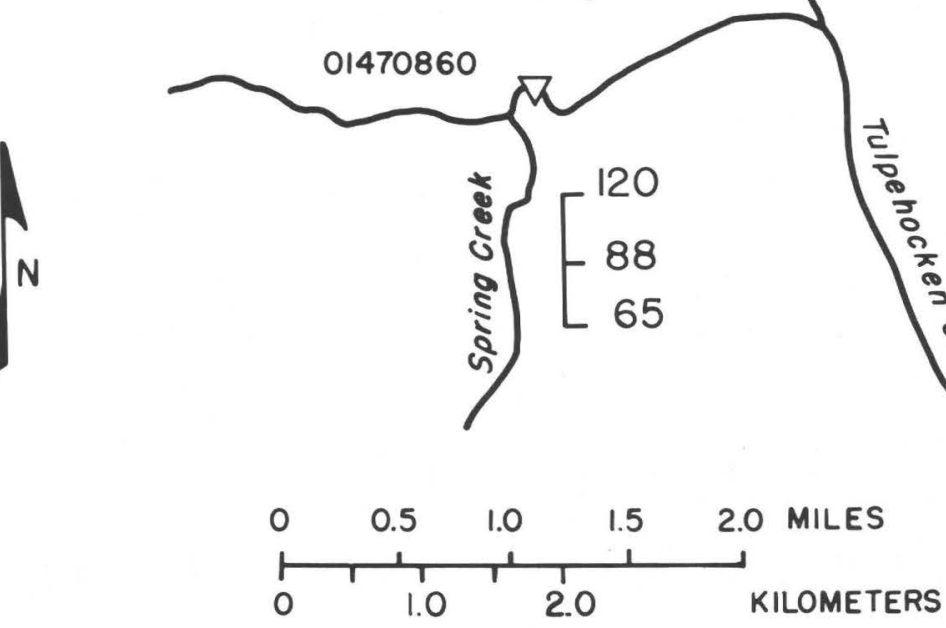

Figure 7.--Map showing total alkalinity in the Tulpehocken Creek basin. 


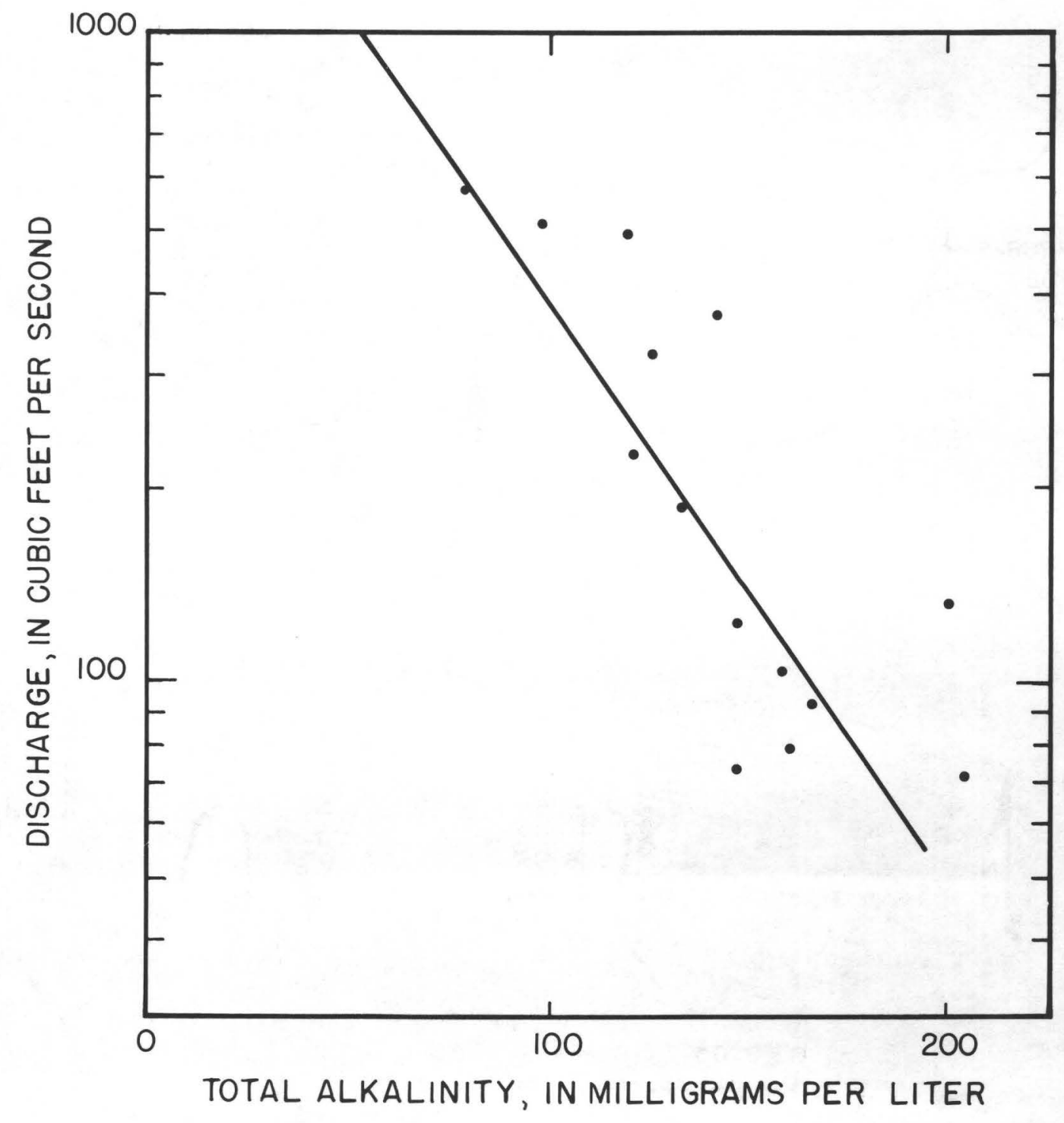

Figure 8.--Graph showing relation between discharge and total alkalinity in the Tulpehocken Creek basin. 


\section{EXPLANATION}

Dissolved oxygen, in milligrams per liter

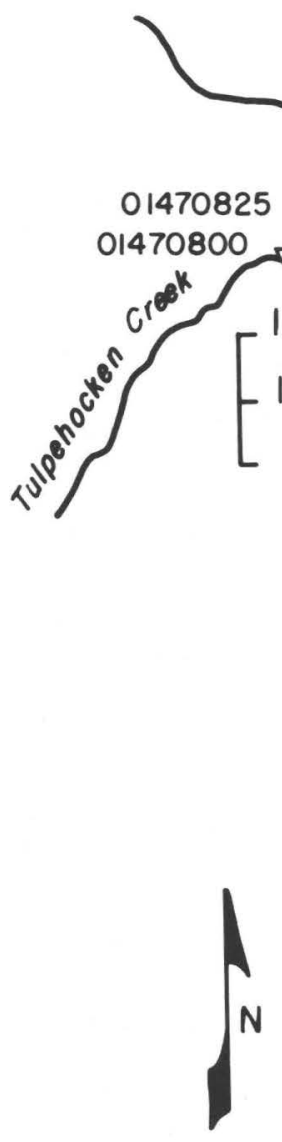

$\left[\begin{array}{r}17.0 \\ 12.4 \\ 6.6\end{array}\right.$

01470825

- Maximum

- Median

L Minimum

$\nabla$ Gaging station and number
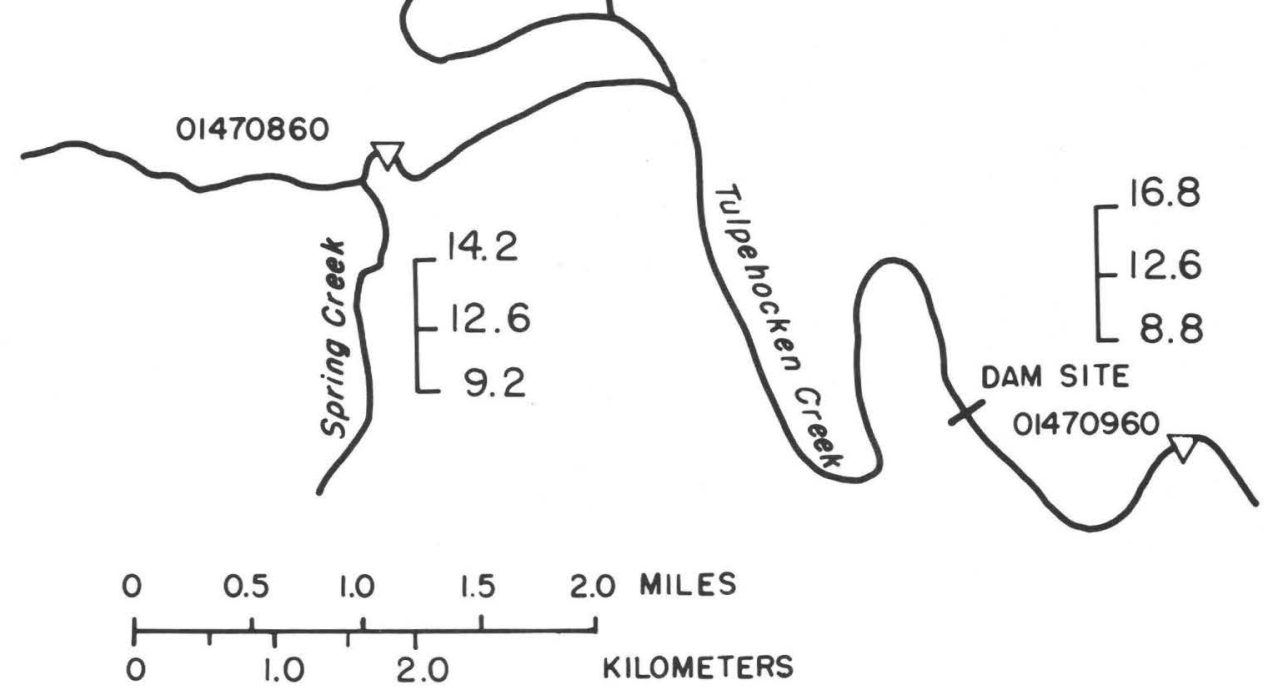

Figure 9.--Map showirig dissolved oxygen concentrations in the Tulpehocken Creek basin. 
EXPLANATION

Specific conductance, in micromhos per centimeter at 25 degrees celsius
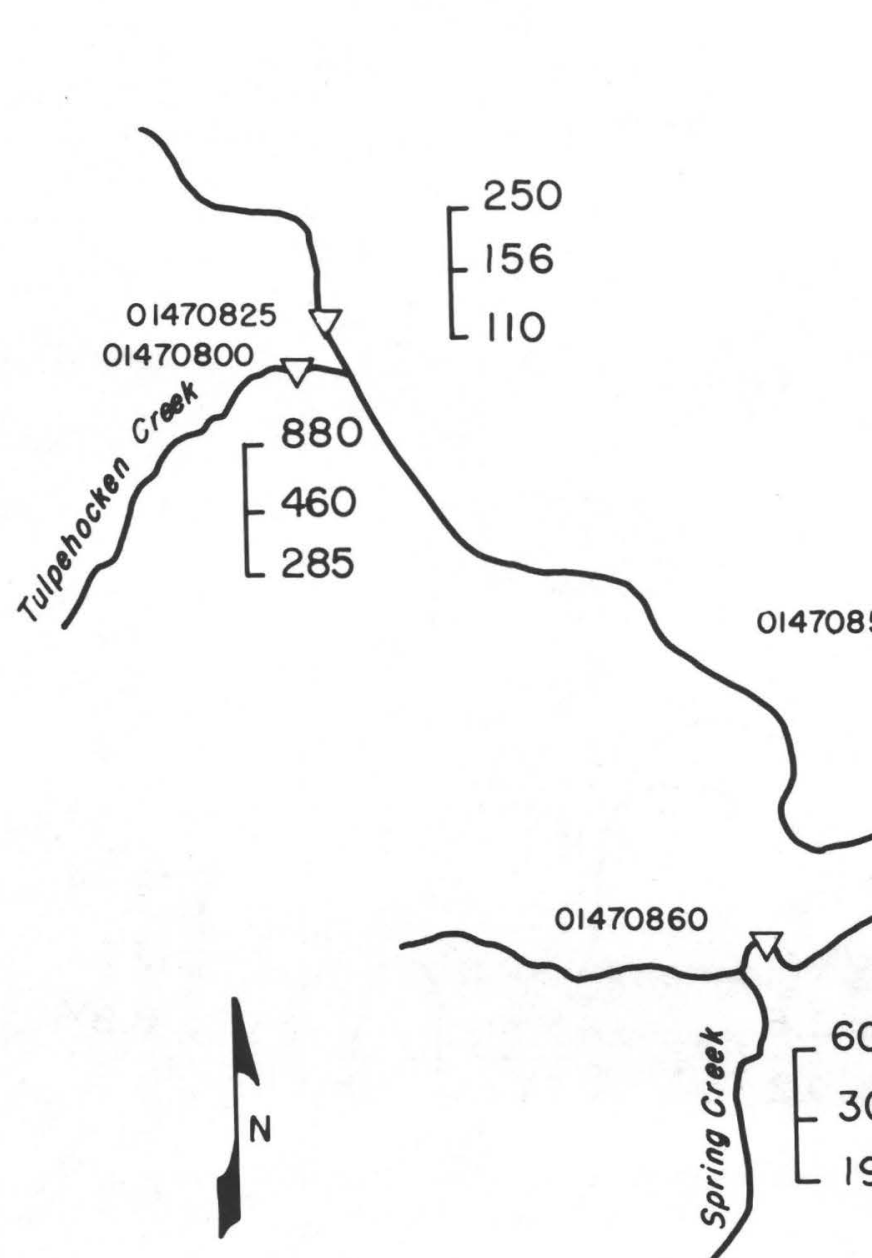


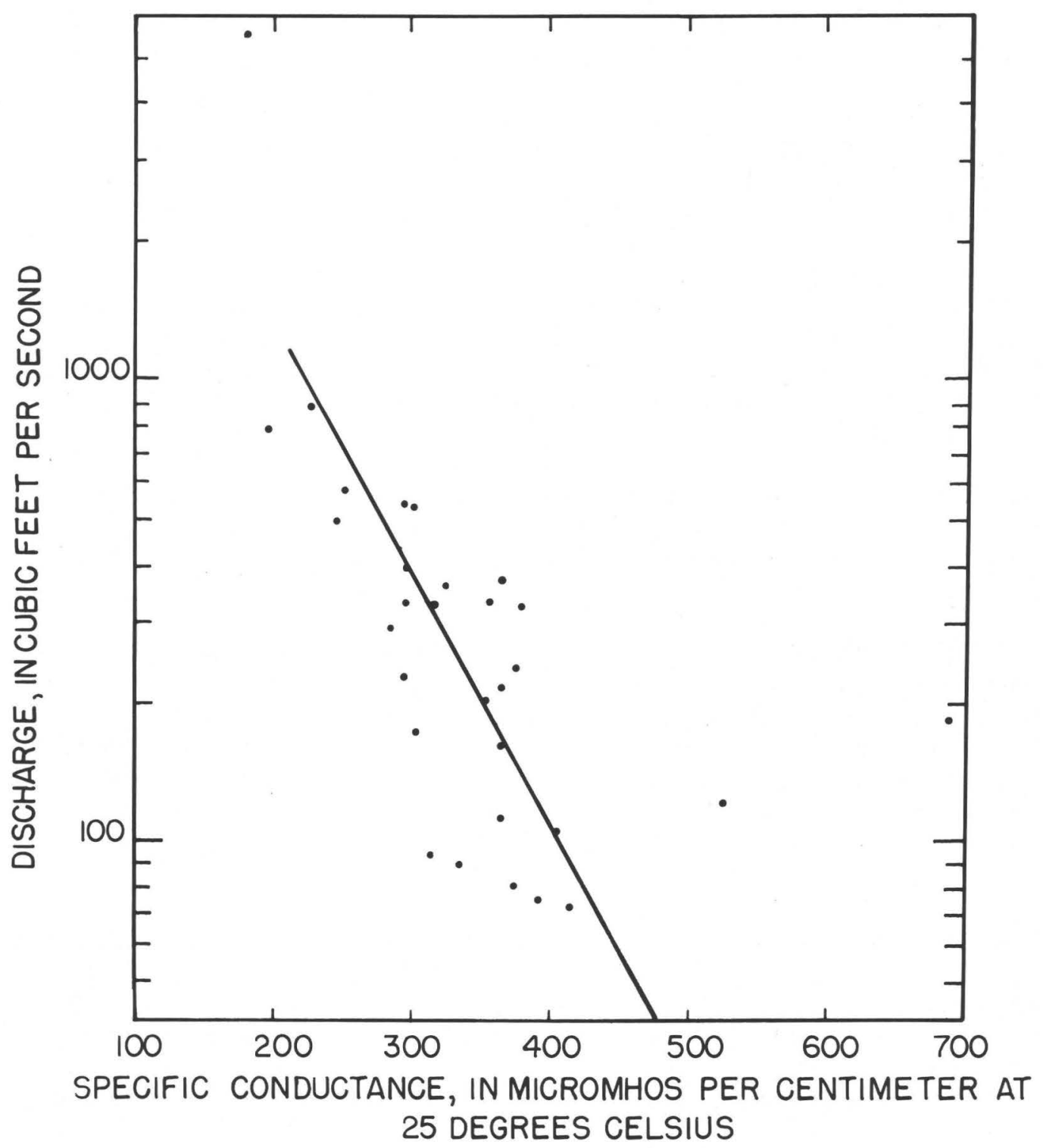

Figure 11.--Graph showing relation hetween discharge and specific conductance in the Tulpehocken Creek basin near Blue Marsh Lake basin. 


\section{Nutrients and Organic Carbon}

\section{Nitrogen and Phosphorus}

of the 21 elements known to be essential for plant growth (Greeson, 1971), nitrogen and phosphorus are the two most of ten associated with limiting growth and reproduction in an aquatic environment. Many studies have demonstrated that if concentrations of these two elements are high, algae blooms often result; if concentrations are low, algae blooms occur infrequently. The concentrations of nitrogen and phosphorus necessary at the beginning of the growing season to produce nuisance populations of algae were suggested by Sawyer (1974) to be 0.30 and $0.015 \mathrm{mg} / \mathrm{L}$, respectively.

In Tulpehocken Creek concentrations of nitrogen and phosphorus exceeded Sawyer's critical values in all of the samples collected within the lake site (fig. 12 and 13). Median concentrations of nitratenitrogen and total phosphorus near the dam site were 4.5 and $0.13 \mathrm{mg} / \mathrm{L}$, respectively. Nutrient concentrations were higher during periods of runoff.

Identification of nutrient sources was beyond the scope of this study, however, sewage-treatment plants, and sources of industrial and agricultural wastes are numerous and provide a continuous and readily available source of nutrients.

The load of nitrogen and phosphorus at various discharges is plotted in figures 14 and 15. Based upon flow duration, the annual input of nitrogen to the lake is about 1,400 tons ( 1,270 metric tons) or 8 tons (7.3 metric tons) per square mile, and the annual input of phosphorus is 46 tons ( 41.7 metric tons) or 0.26 tons ( 0.24 metric tons) per square mile.

\section{Total Organic Carbon (TOC)}

The concentration of organic carbonaceous material in the streams is evaluated as a measure of oxidizable organic matter, or oxygen demand. The median concentrations of 3 to $4 \mathrm{mg} / \mathrm{L}$ at all stations are approximately the concentrations found in similar waters elsewhere and are somewhat higher than in unpolluted waters of similar origin. The highest concentrations were found during periods of high discharge and high sediment load (fig. 16).

\section{Bacteria}

The results of membrane filtration for total and fecal coliform and fecal streptococci bacteria are summarized in figures 17 to 19。 Populations of fecal bacteria were found in sufficient density to indicate serious fecal contamination. The main-stem stations usually contained the highest bacterial densities. 


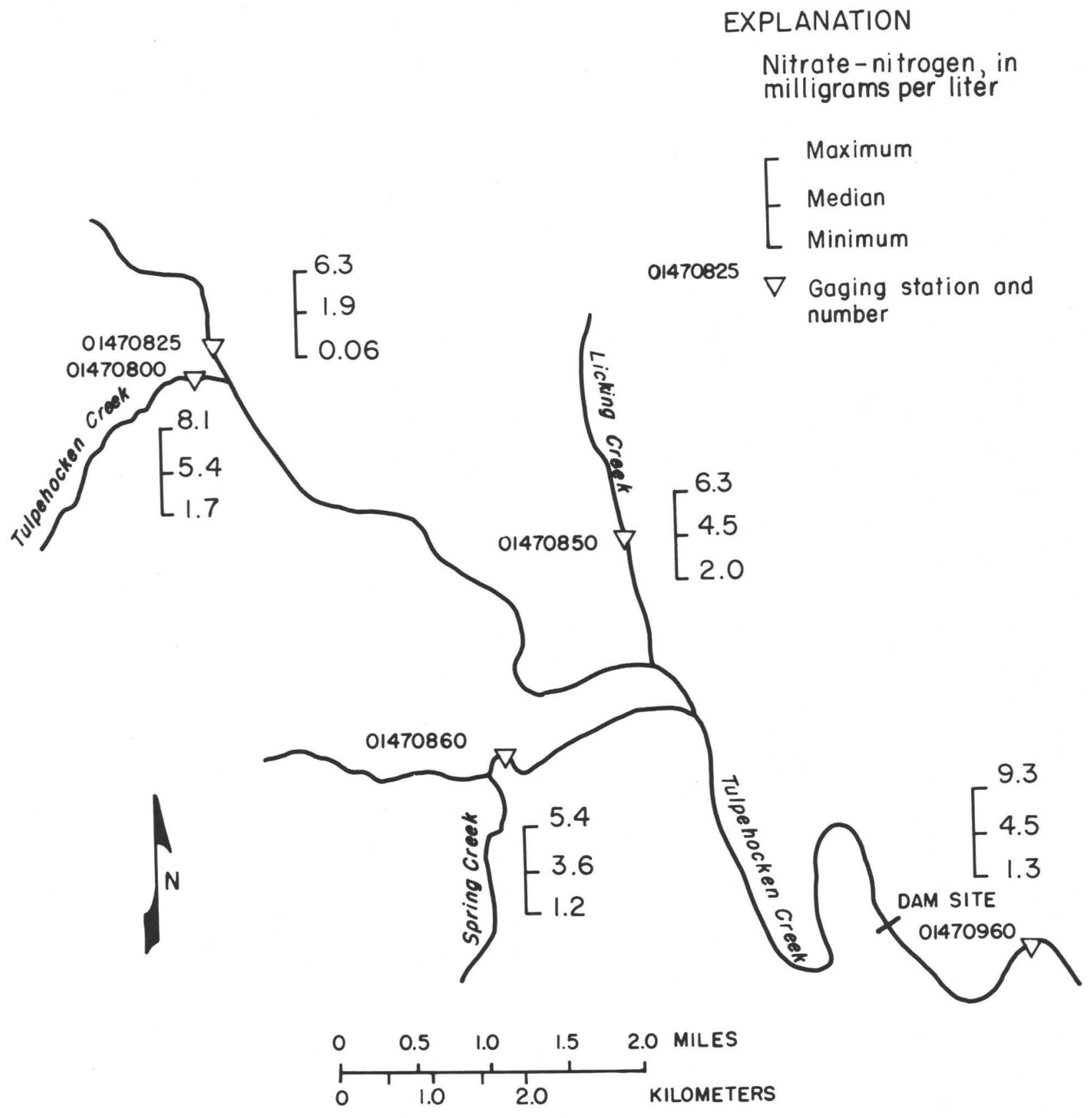

Figure 12.--Map showing nitrate-nitrogen concentrations in the Tulpehocken Creek basin. 


\section{EXPLANATION}

Total phosphorous, in milligrams per liter

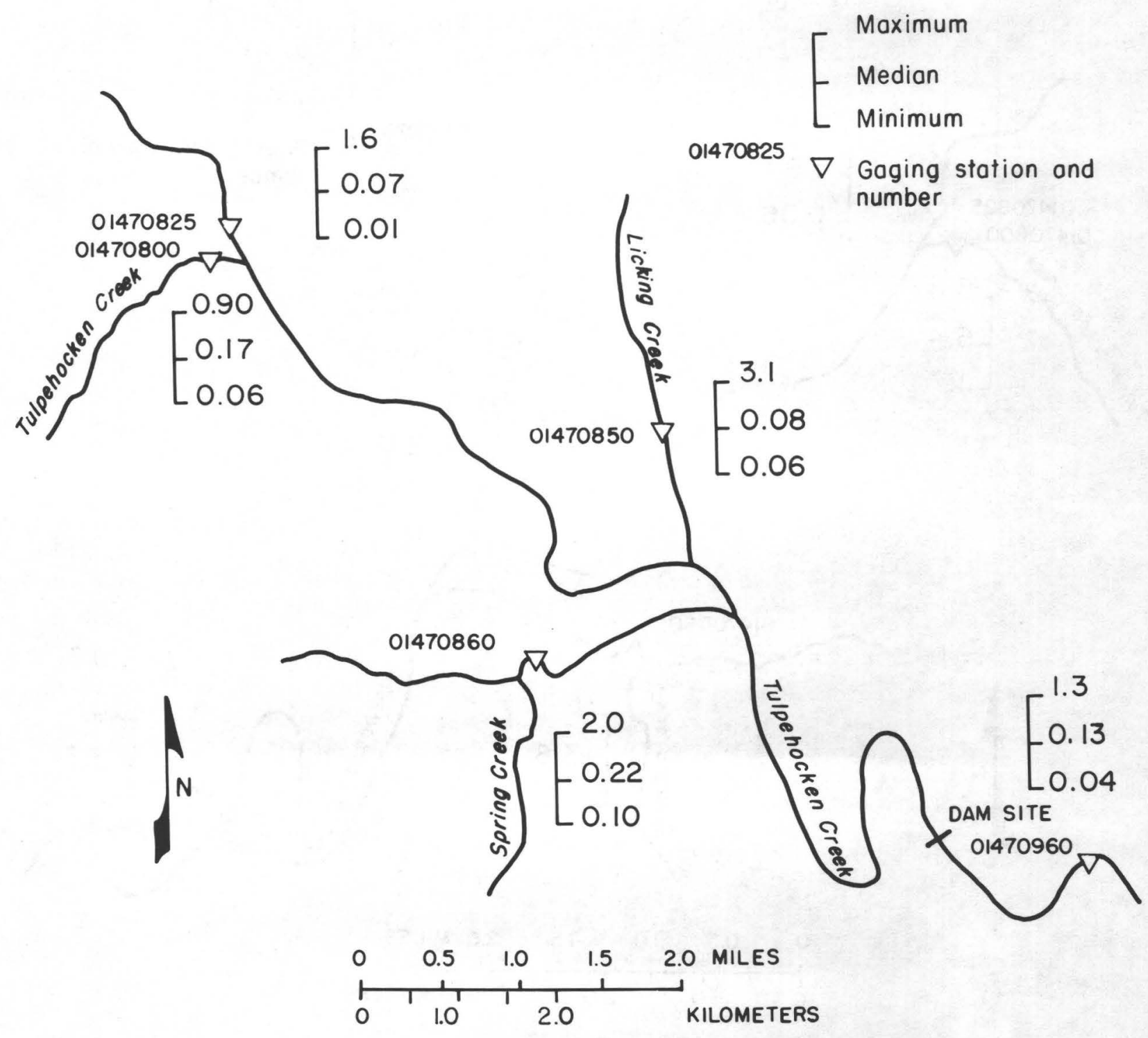

Figure 13.--Map showing total phosphorus concentrations in Tulpehocken Creek basin. 


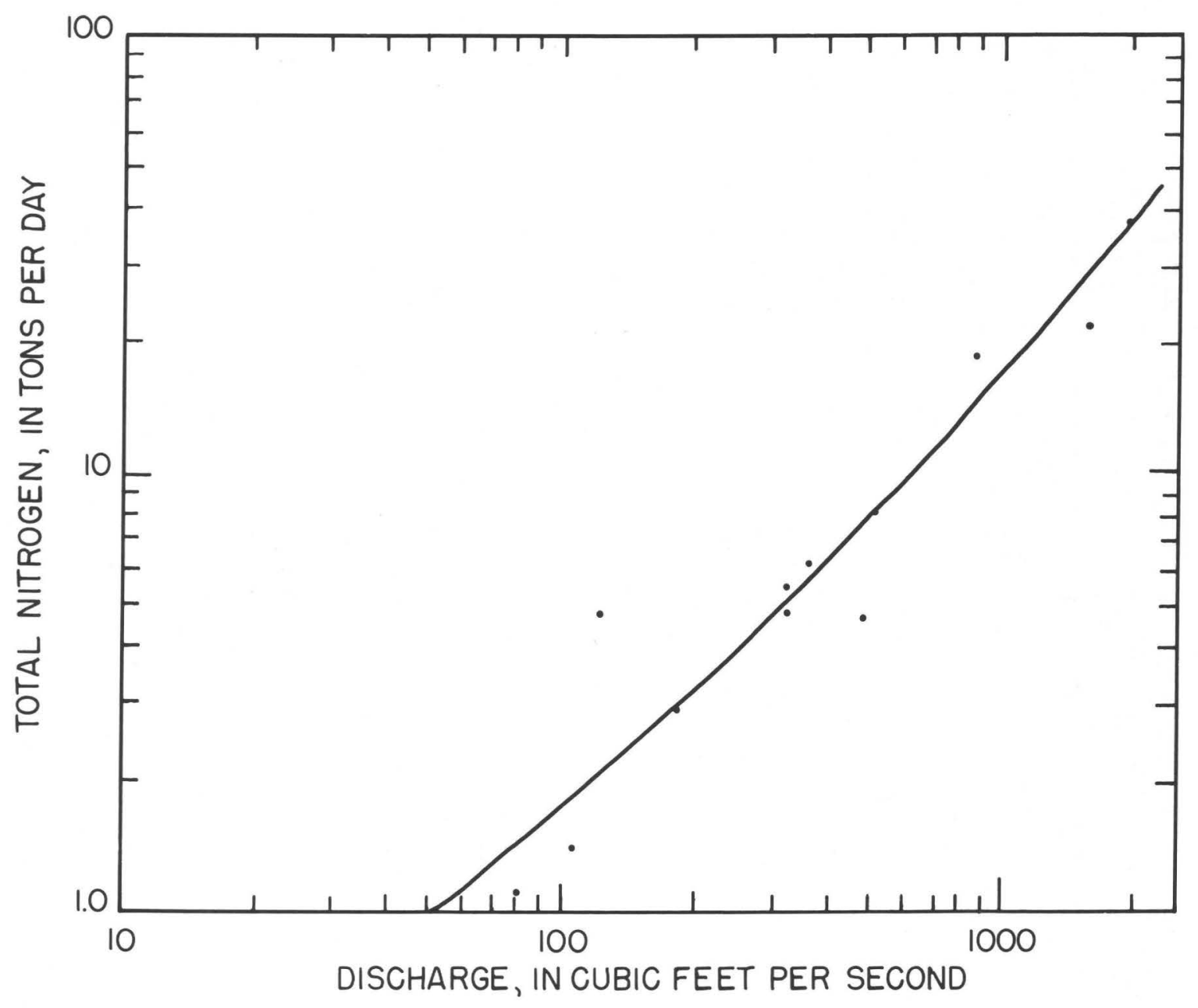

Figure 14.--Graph showing relation between discharge and total nitrogen in Tulpehocken Creek basin near Blue Marsh Dam site. 


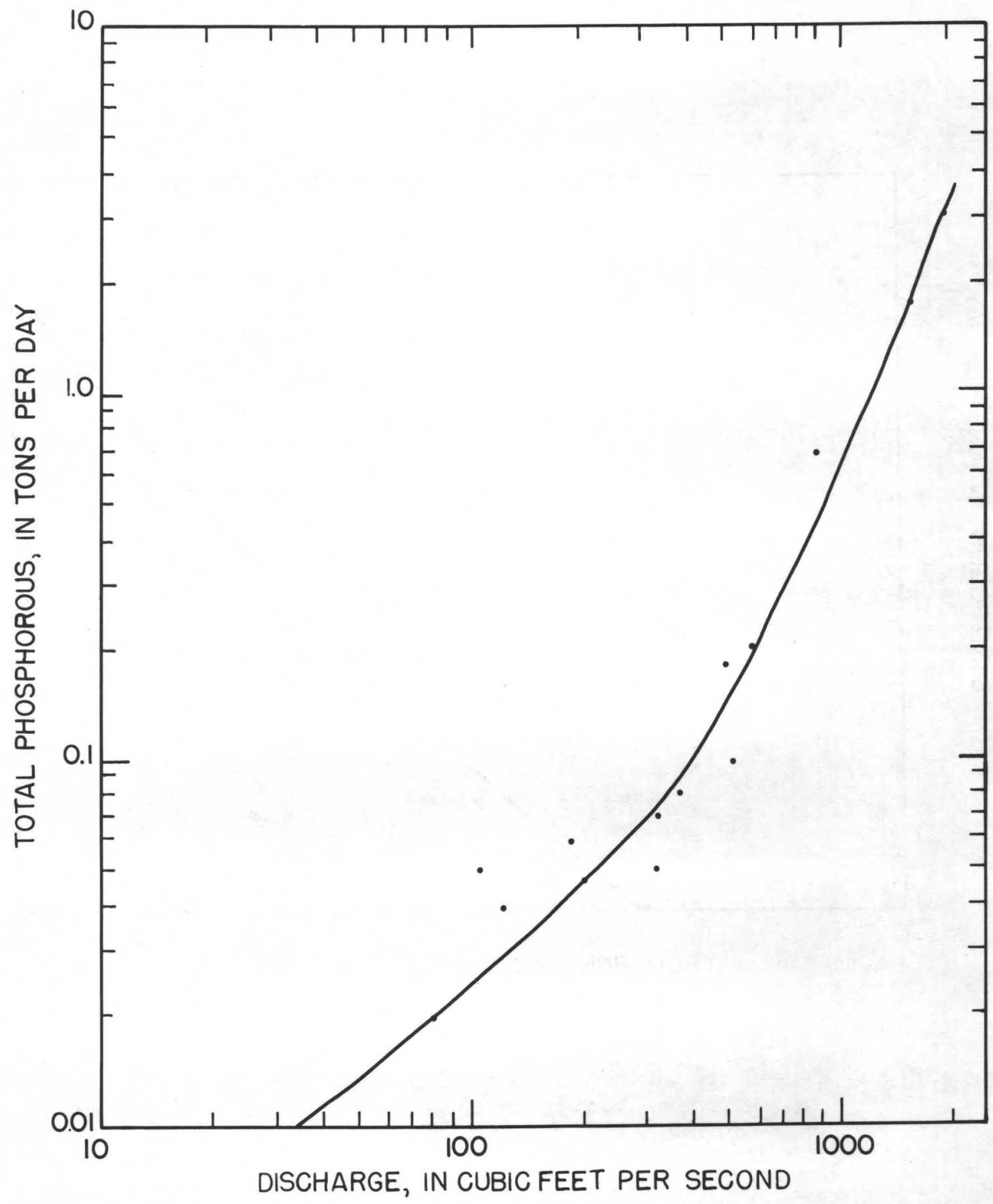

Figure 15.--Graph showing relation between discharge and total phosphorus in Tulpehocken Creek basin near Blue Marsh Dam site. 


\section{EXPLANATION}

Total organic carbon, in milligrams per liter
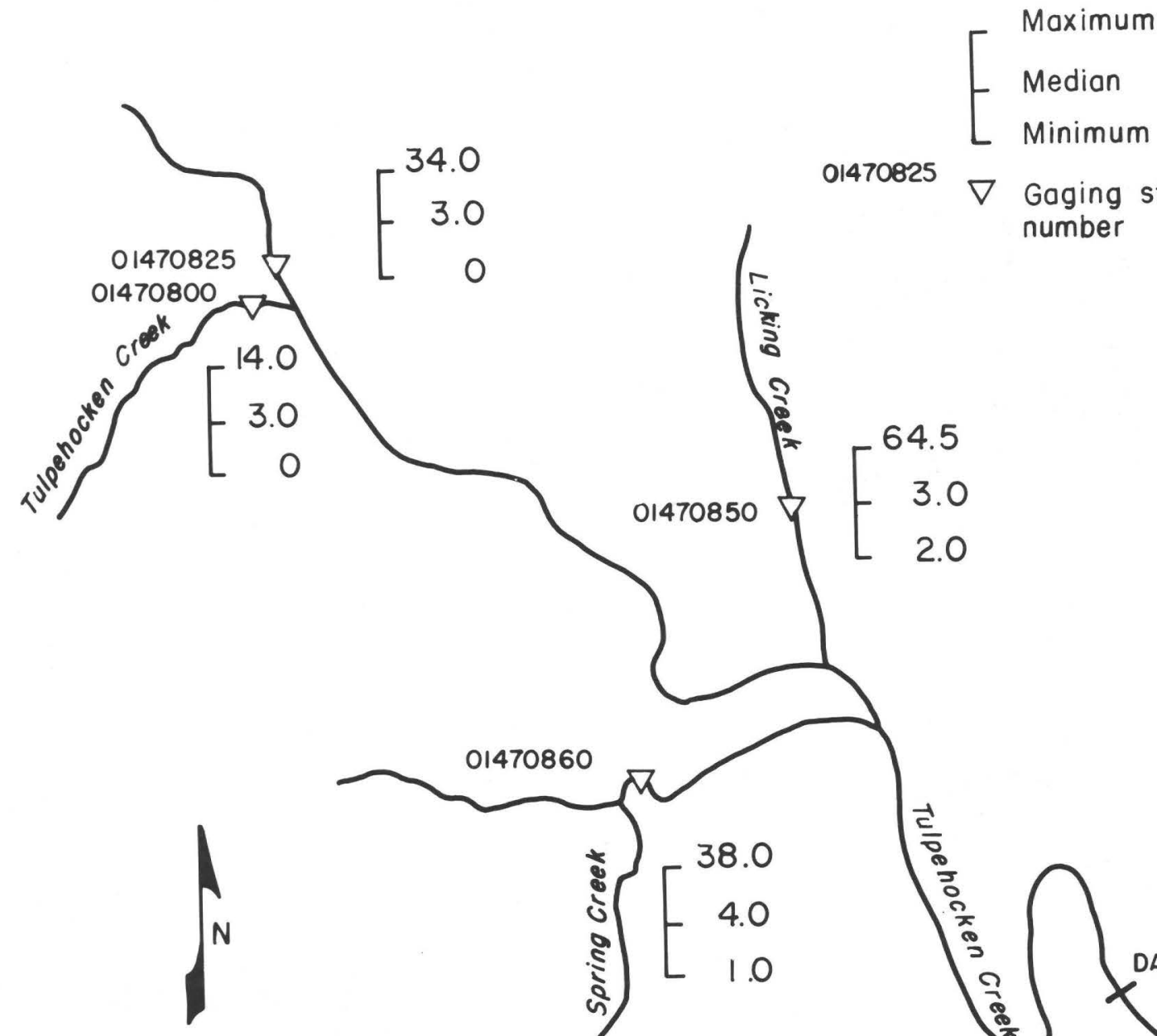

01470825

$\nabla$ Gaging station and number
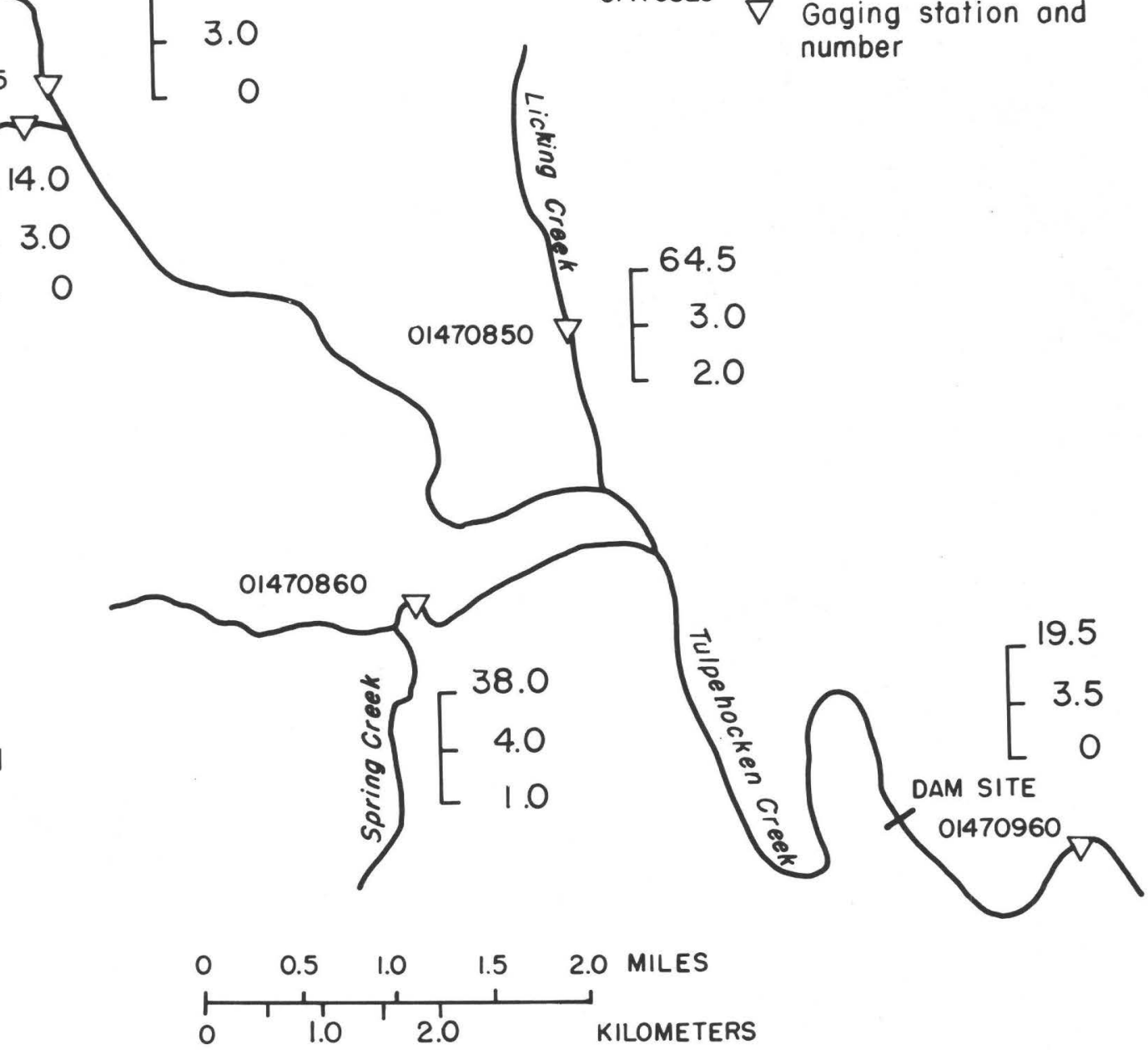

Figure 16.--Map showing concentrations of total organic carbon in Tulpehocken Creek basin. 


\section{EXPLANATION}

Total coliform, in number per 100 milliliter

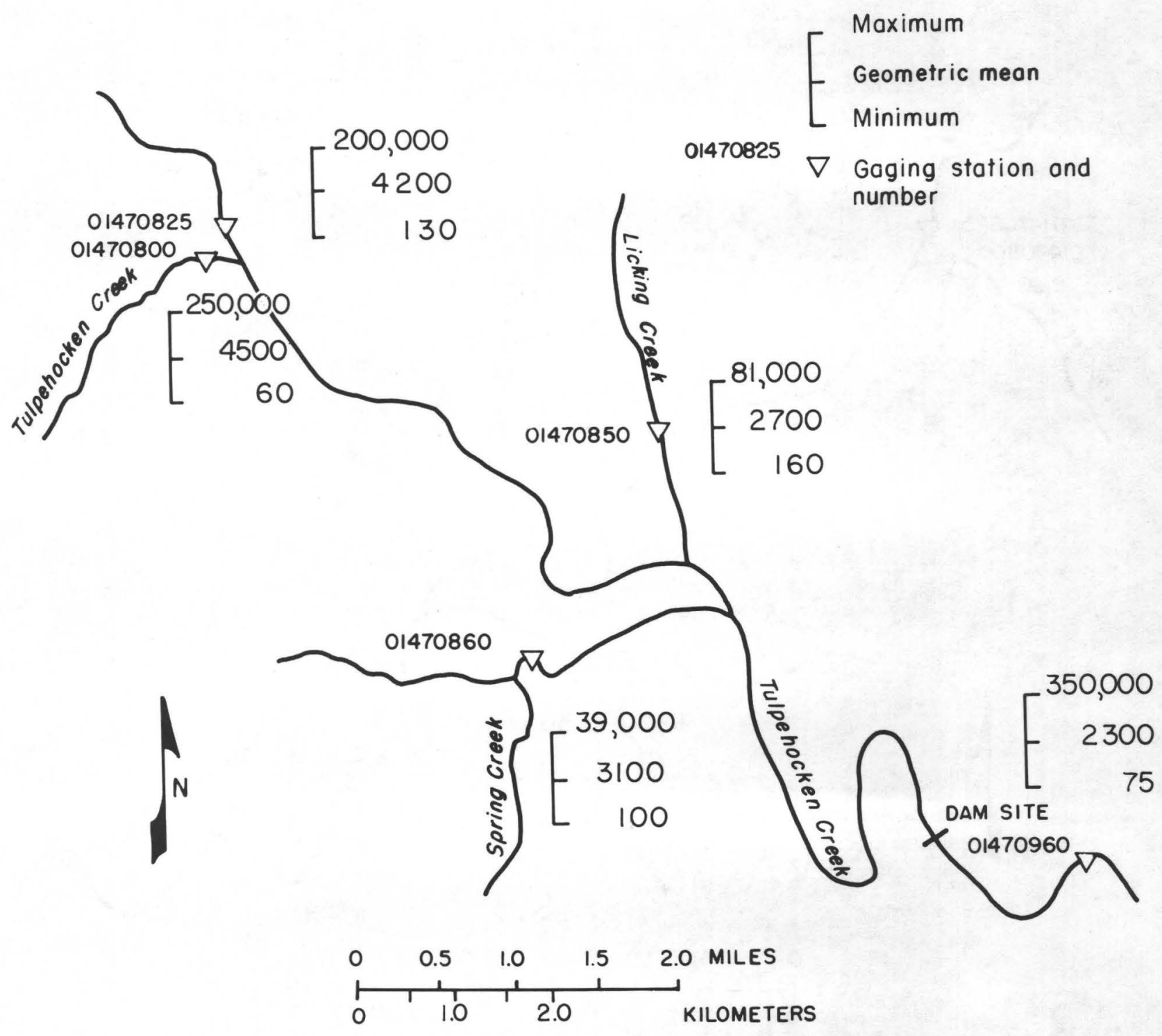

Figure 17.--Map showing concentrations of total coliform in Tulpehocken Creek basin. 


\section{EXPLANATION}

Fecal coliform, in number per 100 milliliter

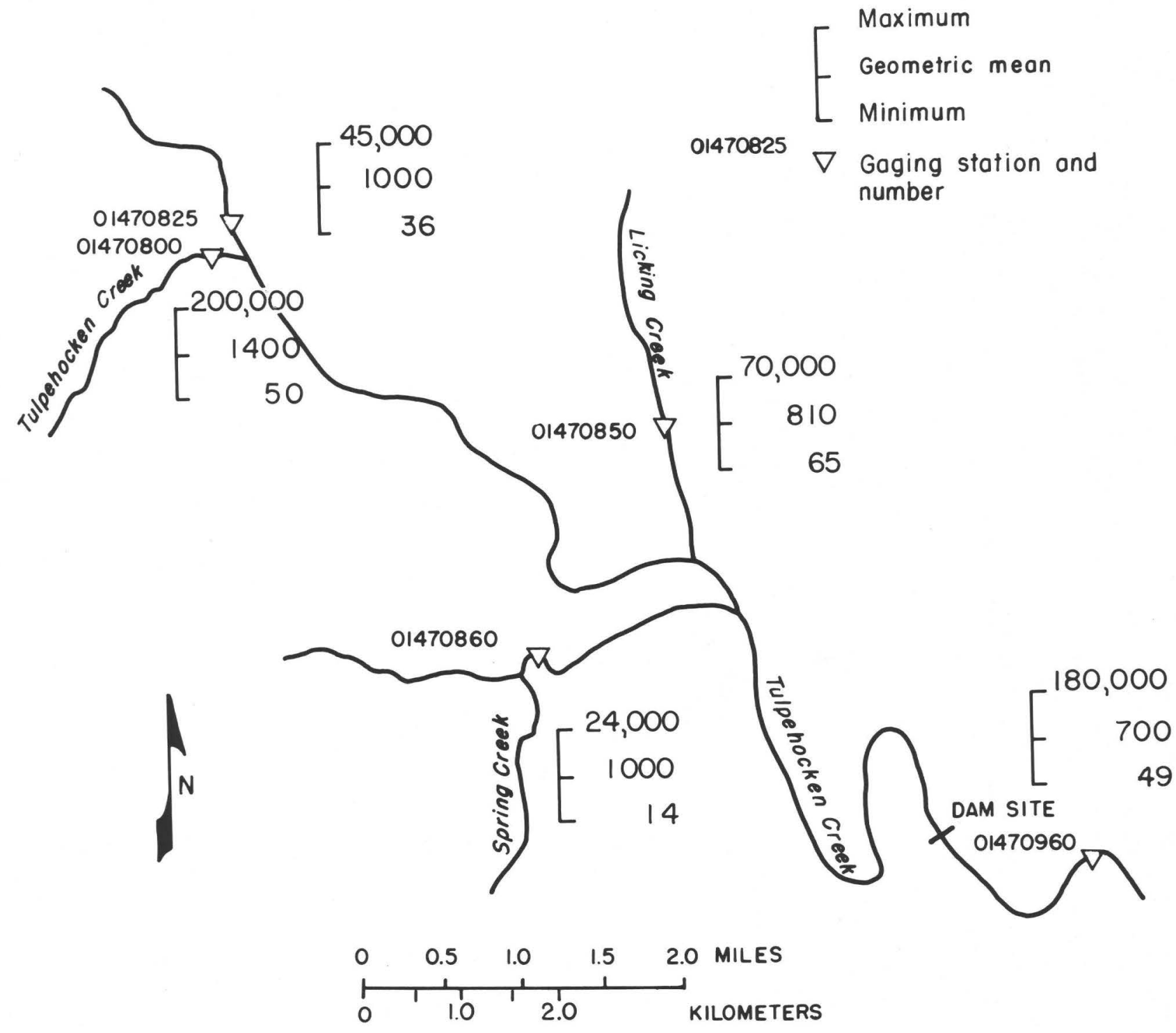

Figure 18.--Map showing concentrations of fecal coliform in Tulpehocken Creek basin. 


\section{EXPLANATION}

Fecal streptococci, in number per 100 milliliter

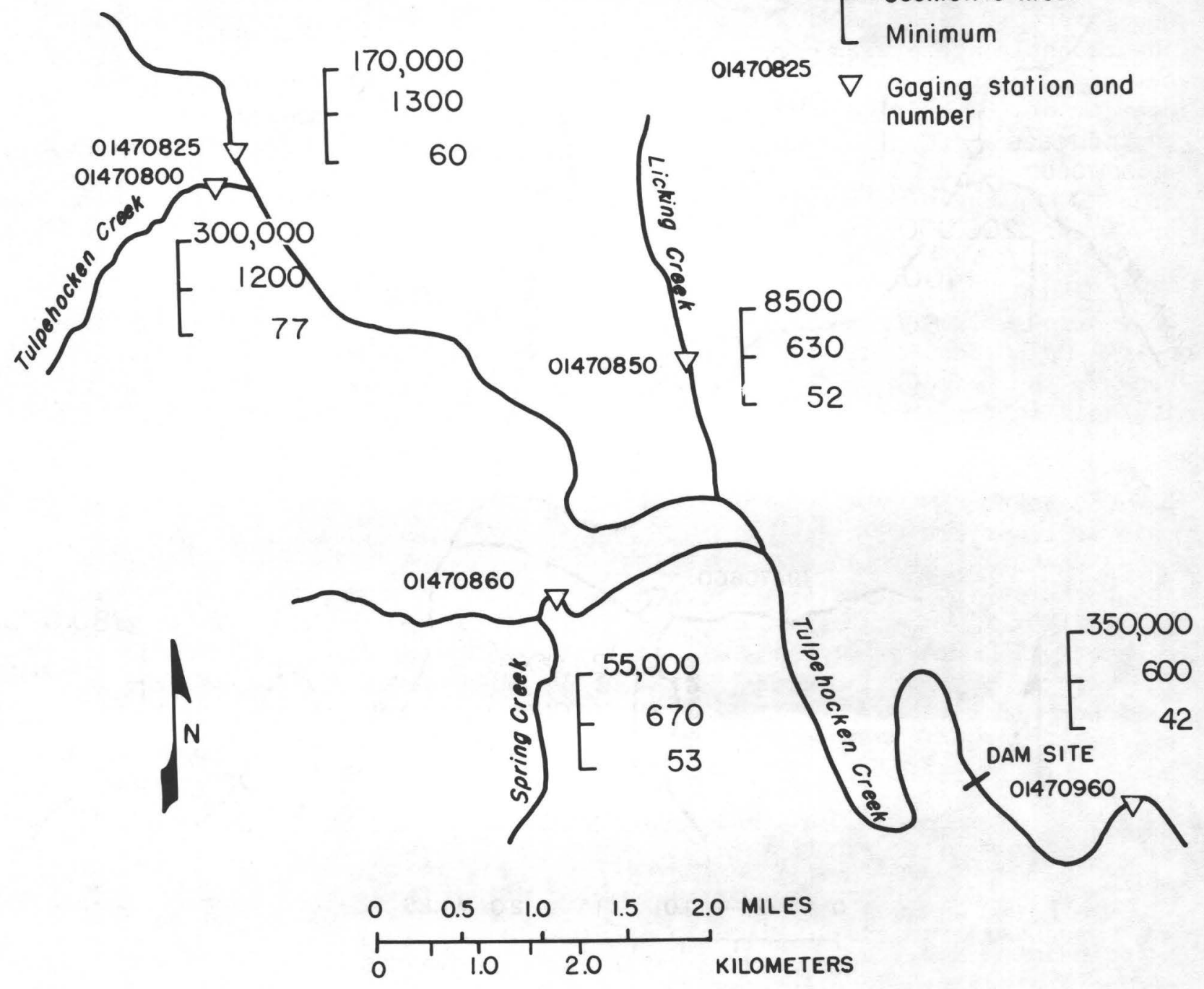

Figure 19.--Map showing concentrations of fecal streptococci in Tulpehocken Creek basin. 
Total coliforms exceeded the recommended national water quality standards for public water supply (U.S. Dept. of the Interior, 1968) of 10,000 per $100 \mathrm{mg}$ in 20 percent of the samples collected near the Blue Marsh Dam site. The Pennsylvania bathing-water standard of 1,000 per 100 $\mathrm{ml}$ was also exceeded in 10 out of 12 samples collected during the months of June to September. The maximum density of 350,000 per $100 \mathrm{ml}$ was measured after a heavy rain in October 1973.

Fecal coliforms, a better indicator of recent fecal pollution, exceeded the recommended 2,000 per $100 \mathrm{~m} 1$ for public water supplies (U.S. Dept. of the Interior, 1968) in 29 percent of the samples. Fecal coliforms exceeded the recently accepted 200 per $100 \mathrm{ml}$ bathing-water standard, also, in 10 out of 12 samples collected between June and September. The maximum density of 200,000 fecal coliform per $100 \mathrm{ml}$ was found in those samples that contained the maximum density of total coliforms. Maximum bacterial densities were found to correspond with precipitation and subsequent runoff, whereas minimum densities correspond with prolonged dry periods and occur chiefly during late autumn and winter.

Mean densities of bacteria decreased 50 percent in the $8 \mathrm{mi}(13 \mathrm{~km})$ and approximately 12-hour travel time at mean flow between the two stations on the main stem. The degree to which the bacteria are reduced is significant because the utility of the lake, once impounded, may well be determined by its ability to purify itself of the pollutional load。

The bacterial mortality rate for the impounded waters is difficult to predict because of the many environmental factors that affect the population, such as temperature, sedimentation, and predation. A study at Belmont Lake, Michigan, on the Huron River (Smith and Twedt, 1971) indicated that the bacterial mortality from the point of inflow into the lake to the dam, $11 \mathrm{mi}(17.7 \mathrm{~km})$ downstream, was 40 percent, 85 percent, and 96 percent, respectively, for total coliform, fecal coliform, and fecal streptococci. The report does not indicate the retention time between inflow and the dam, but, if a similar mortality rate for Blue Marsh Lake is assumed, bacterial water-quality standards for water-contact recreation would be at acceptable levels during periods of normal flow, but may be exceeded 4 out of 10 days during June-September, if the inflows exceed $200 \mathrm{ft}^{3} / \mathrm{s}(5.6$ $\left.\mathrm{m}^{3} / \mathrm{s}\right)$.

\section{Sediment and Bed Material}

Sediment movement in Tulpehocken Creek is a major problem. High sediment discharge deteriorates water and limits its use, shortens the life of impoundments, increases water-treatment costs, alters or destroys aquatic life, and impairs the esthetic value of recreational waters. 
Figure 20, commonly called a daily sediment-transport curve, shows the relation of sediment discharge to water discharges greater than 100 $\mathrm{ft}^{3} / \mathrm{s}\left(2.8 \mathrm{~m}^{3} / \mathrm{s}\right)$ in Tulpehocken Creek at Blue Marsh Dam site. Monthly discharge of runoff and sediment is highest in winter and early spring (February to April), as the result of rain and snowmelt. Severe storms, such as the hurricanes in 1955 and 1972, also cause high runoff and sediment discharge.

Suspended-sediment concentrations between January 1973 and Apri1 1975 ranged from $7 \mathrm{mg} / \mathrm{L}$, at base flow, to $1,850 \mathrm{mg} / \mathrm{L}$ at maximum runoff. Daily sediment discharges ranged from one to 8,350 tons $(0.9$ and 7,575 metric tons).

Bed-material samples from the top 1 in $(2.54 \mathrm{~cm})$ were collected at the five sampling sites in October 1972 and June 1974. Results of the physical and chemical analyses are presented in tables 7, 8, and 9. Bedmaterial analyses indicate a highly fertile bed material of ideal composition for growing rooted plants. With the exception of mercury, higher concentrations of trace metals were noted in 1972 than 1974.

Insecticide residues were of low leve1, with trace concentrations of aldrin, dieldrin, chlordane, and DDT plus its metabolites. Polychlorinated biphenyls (PCB) ranged from 10 to $100 \mu \mathrm{g} / \mathrm{kg}$ (microgram per kilogram), suggesting the presence of industrial effluent.

Arsenic concentrations in more than 80 samples of water and suspended sediment were determined during January 4, 1973, to April 26, 1975. (See table 11.) Concentrations ranged from 0 to $30 \mu \mathrm{g} / \mathrm{L}$ in the water and from 2 to $879 \mathrm{\mu} / \mathrm{g}$ in the suspended sediment. Concentrations of total arsenic ranged from 2.2 to $48.8 \mu \mathrm{g} / \mathrm{L}$. The data collected to date suggest that total arsenic concentrations have decreased during the past 2 years. Concentrations are highest in the sediment during periods of low sediment concentration (fig. 21), but the total arsenic load is highest during periods of high discharge (fig. 22).

Faust and Clement (1973) and Wood (1973) investigated the arsenic problem and agree that concentrations reaching Blue Marsh Lake will rarely exceed $50 \mu \mathrm{g} / \mathrm{L}$ (micrograms per liter). Although the Environmental Protection Agency (EPA) National Drinking Water Standard of $50 \mu \mathrm{g} / \mathrm{L}$ arsenic was not exceeded in any of the samples analyzed, the annual load of arsenic discharged to Tulpehocken Creek was computed to be 3.9 tons ( 3.5 metric tons). Its environmental effects, however, have not been fully investigated.

\section{SOILS}

The fertility of inundated soils is probably significant in the storage and release of certain nutrients that could be deleterious to a new impoundment. Carbon, nitrogen, and phosphorus are essential to the growth of plant life that are primary in determining soil fertility. 


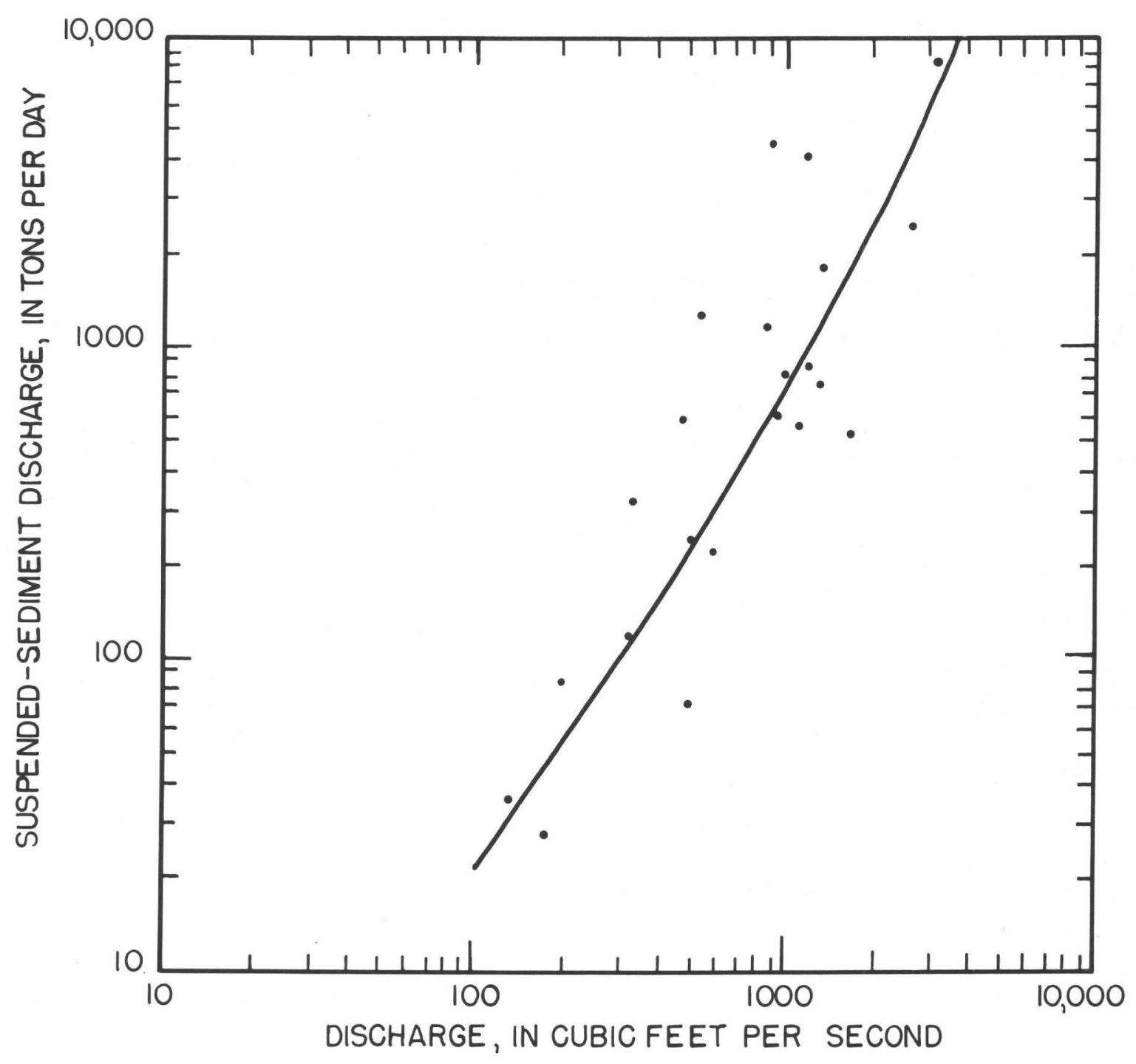

Figure 20.--Graph showing daily sediment transport curve (1973) for TuZpehocken Creek basin near Blue Marsh Dam site. 
Table 7.--Particle-size and nutrient conStation Date

Sand Silt Clay Percent

10-17-72 6-18-74

Bernville

Northkill Creek below Little Northkil1 Creek at Bernville

Licking Creek near Bernville

Tulpehocken Creek at Blue Marsh dam site near Reading--------------

Spring Creek near Reading-- - - -
10-17-72

6-18-74

$10-17-72$

$$
\begin{array}{r}
10-17-72 \\
6-18-74
\end{array}
$$

$$
9.2
$$

30.8

78.4

38.4

12.4

30.8

10-17-72

52.6

37.7

9.7 
tent of bed material in Tulpehocken Creek.

\begin{tabular}{|c|c|c|c|c|c|c|c|c|}
\hline \multicolumn{3}{|c|}{ Carbon } & \multicolumn{3}{|c|}{ Nitrogen } & \multicolumn{3}{|c|}{ Phosphorus } \\
\hline $\begin{array}{l}\text { Inor- } \\
\text { ganic }\end{array}$ & Organic & Total & $\begin{array}{l}\text { Inor- } \\
\text { ganic }\end{array}$ & Organic & Total & $\begin{array}{l}\text { Inor- } \\
\text { ganic }\end{array}$ & Organic & Total \\
\hline & & & Microgr & ams per & ilogran & & & \\
\hline $\begin{array}{r}0.3 \\
.4\end{array}$ & $\begin{array}{l}1.7 \\
2.2\end{array}$ & $\begin{array}{l}2.0 \\
2.6\end{array}$ & $\begin{array}{r}260 \\
20\end{array}$ & $\begin{array}{l}2,100 \\
2,300\end{array}$ & $\begin{array}{l}2,360 \\
2,320\end{array}$ & -- & -- & $\begin{array}{l}790 \\
386\end{array}$ \\
\hline .0 & 2.4 & 2.4 & 260 & 2,100 & 2,360 & -- & -- & 550 \\
\hline .0 & 2.3 & 2.3 & 20 & 2,200 & 2,220 & -- & -- & 219 \\
\hline .1 & 2.9 & 3.0 & 120 & 4,000 & 4,120 & -- & -- & 1,100 \\
\hline .4 & 2.6 & 3.0 & 520 & 2,900 & 3,420 & -- & -- & 1,100 \\
\hline .4 & 2.1 & 2.5 & 40 & 2,880 & 2,920 & -- & -- & 674 \\
\hline .1 & 1.5 & 1.6 & 230 & 1,700 & 1,930 & -- & -- & 970 \\
\hline
\end{tabular}


Table 8.--Concentrations of selected

\begin{tabular}{|c|c|c|c|c|c|}
\hline Station & Date & $\begin{array}{l}\text { Iron } \\
(\mathrm{Fe})\end{array}$ & $\begin{array}{c}\text { Manga- } \\
\text { nese } \\
(\mathrm{Mn}) \\
\end{array}$ & $\begin{array}{c}\text { Copper } \\
(\mathrm{Cu})\end{array}$ & $\begin{array}{l}\text { Nicke1 } \\
(\mathrm{Ni})\end{array}$ \\
\hline $\begin{array}{l}\text { Tulpehocken Creek } \\
\text { at Bernville- }\end{array}$ & $\begin{array}{r}10-17-72 \\
6-18-74\end{array}$ & $\begin{array}{r}16,500 \\
5,600\end{array}$ & $\begin{array}{r}1,300 \\
910\end{array}$ & $\begin{array}{l}20 \\
12\end{array}$ & $\begin{array}{r}15 \\
8\end{array}$ \\
\hline Northkill Creek below & & & & & \\
\hline $\begin{array}{l}\text { Little Northkill Creek } \\
\text { at Bernville- }\end{array}$ & $\begin{array}{r}10-17-72 \\
6-18-74\end{array}$ & $\begin{array}{r}21,000 \\
7,500\end{array}$ & $\begin{array}{l}630 \\
670\end{array}$ & $\begin{array}{l}21 \\
10\end{array}$ & $\begin{array}{r}18 \\
9\end{array}$ \\
\hline $\begin{array}{l}\text { Licking Creek near } \\
\text { Bernville- }\end{array}$ & $10-17-72$ & 18,000 & 960 & 19 & 14 \\
\hline $\begin{array}{l}\text { Tulpehocken Creek at } \\
\text { Blue Marsh dam site } \\
\text { near Reading- }\end{array}$ & $\begin{array}{r}10-17-72 \\
6-18-74\end{array}$ & $\begin{array}{r}18,000 \\
4,600\end{array}$ & $\begin{array}{r}1,000 \\
690\end{array}$ & $\begin{array}{r}25 \\
7\end{array}$ & $\begin{array}{r}12 \\
6\end{array}$ \\
\hline $\begin{array}{l}\text { Spring Creek near } \\
\text { Reading }\end{array}$ & $10-17-72$ & 19,000 & 900 & 18 & 13 \\
\hline
\end{tabular}


elements in bed material in Tulpehocken Creek.

\begin{tabular}{|c|c|c|c|c|c|c|c|c|}
\hline \multicolumn{6}{|c|}{ Extractable } & \multicolumn{3}{|c|}{ Total } \\
\hline $\begin{array}{l}\text { Lead } \\
(\mathrm{Pb})\end{array}$ & $\begin{array}{l}\text { Zinc } \\
(\mathrm{Zn})\end{array}$ & $\begin{array}{l}\text { Cad- } \\
\text { mium } \\
\text { (Cd) }\end{array}$ & $\begin{array}{c}\text { Cobalt } \\
(\mathrm{Co})\end{array}$ & $\begin{array}{c}\text { Chrom- } \\
\text { ium } \\
\text { (Cr) }\end{array}$ & $\begin{array}{l}\text { Alum- } \\
\text { inum } \\
\text { (A1) }\end{array}$ & $\begin{array}{c}\text { Selen- } \\
\text { ium } \\
\text { (Se) }\end{array}$ & $\begin{array}{l}\text { Mer- } \\
\text { cury } \\
(\mathrm{Hg}) \\
\end{array}$ & $\begin{array}{c}\text { Arse- } \\
\text { nic } \\
\text { (As) }\end{array}$ \\
\hline \multicolumn{9}{|c|}{ Micrograms per Gram } \\
\hline 69 & 77 & 1 & 12 & 13 & 7,700 & 2 & 0.1 & 79 \\
\hline 25 & 39 & 0 & 7 & 4 & -- & .1 & 23 & 1 \\
\hline 61 & 82 & 1 & 13 & 14 & 8,660 & 3 & .1 & 17 \\
\hline 30 & 49 & 0 & 6 & 0 & -- & .2 & 2.6 & 3 \\
\hline 75 & 75 & 1 & 12 & 15 & 7,800 & 0 & .1 & 10 \\
\hline 150 & 85 & 1 & 12 & 14 & 8,700 & 2 & .2 & 32 \\
\hline 18 & 34 & 1 & 4 & 3 & -- & 0 & 17 & 26 \\
\hline 69 & 83 & 1 & 13 & 14 & 6,800 & 6 & .1 & 9 \\
\hline
\end{tabular}


Table 9.--Insecticide analyses of bed material collected October 17, 1972.

[Results in micrograms per kilogram]

\begin{tabular}{|c|c|c|c|c|c|c|c|c|c|c|}
\hline Station & Aldrin & DDD & DDE & DDT & $\begin{array}{l}\text { Diel- } \\
\text { drin }\end{array}$ & Endrin & $\begin{array}{l}\text { Hepta- } \\
\text { chlor }\end{array}$ & $\begin{array}{l}\text { Lin- } \\
\text { dane }\end{array}$ & $\begin{array}{l}\text { Chlor- } \\
\text { dane I/ }\end{array}$ & $\mathrm{PCB}^{1 /}$ \\
\hline
\end{tabular}

Tulpehocken Creek at Bernville-

$\begin{array}{llllllllll}0.0 & 3.3 & 1.2 & 1.6 & 3.2 & 0.0 & 0.0 & 0.0 & 30 & 50\end{array}$

Northkill Creek below Little Northkill Creek

at Bernville-_-

$9.5 \quad 4.7 \quad 2.5 \quad 1.0 \quad 23$

$.0 \quad .0$

.020

80

Licking Creek near

Bernville-_-_-_-_-_-

$\begin{array}{llllllllll}.9 & 2.0 & 2.5 & 1.4 & 1.8 & .0 & .0 & .0 & 4 & 10\end{array}$

Tulpehocken Creek at

Blue Marsh Dam site

near Reading-

$\begin{array}{lllll}.0 & 4.8 & 2.0 & .9 & 14\end{array}$

$.0 \quad .0$

.010

100

Spring Creek near

Reading--

.7

.5

.0

.0

.0

.01

10

1/ Estimate. 


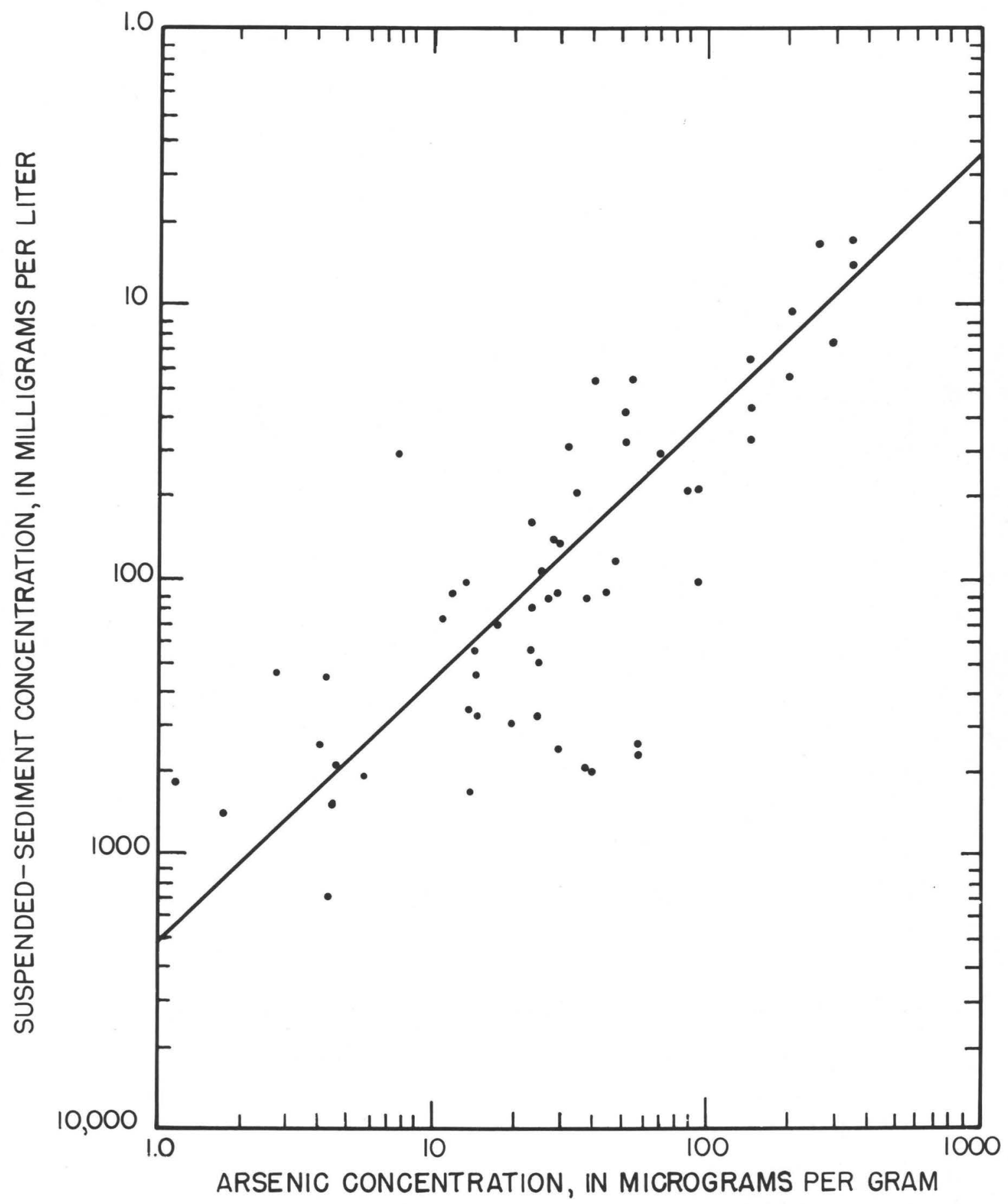

Figure 21.--Graph showing relation between suspended-sediment concentration and arsenic concentration in Tulpehocken Creek near Blue Marsh Dam site. 


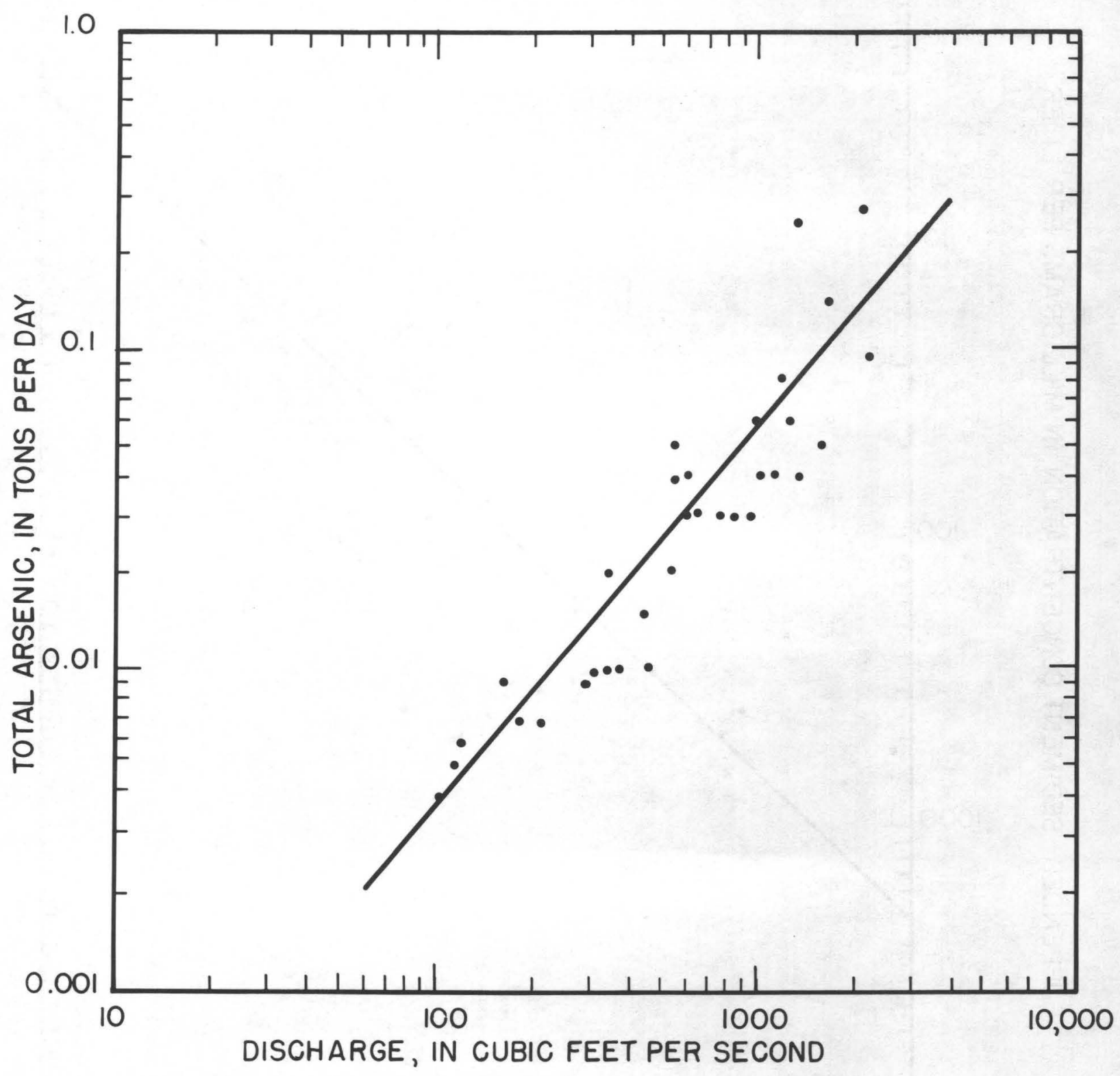

Figure 22.--Graph showing relation between arsenic load and discharge in Tulpehocken Creek basin near Blue Marsh Dam site. 
Samples of the upper 3 in $(7.6 \mathrm{~cm})$ of soil material were collected at five sites on the flood plain of Tulpehocken and Spring Creeks (fig. 1). The sites were selected as representative of the different depositional environments within the impoundment area. Three sites are, or have been, tilled; one is in pasture, and one appeared undisturbed. The results of the physical and nutrient analyses are presented in table 10.

Soils sampled in the Tulpehocken basin flood plain are classified by Ackerman (1970) as belonging to the Atkins, Berks, and Werkert-Berks series and are silt loam or shaly silt loam in texture. He lists productivity of these soils as medium to medium-high based upon an estimated yield in an average growing season. Carbon content ranged from 1.3 to 2.8 percent, nitrogen from 0.13 to 0.46 percent, and phosphorus from 0.002 to 0.024 percent. Carbon-nitrogen ratios ranged from 5.0 to 14.2 . According to Lyon and others (1952), this range of carbon-nitrogen ratios is average for mineral soils in a temperate climate.

Perhaps of greater significance to the ecology of the proposed lake is the silt loam texture of the soil, which is ideal for the attachment and growth of aquatic plants. As stated by Sculthorpe (1967, p. 56), "***The highest population densities and most varied submerged floras occur on fine inorganic silts and clays and organic muds, ***".

\section{RESULTS AND CONCLUSIONS}

The current investigation of the preimpoundment quality of water and the aquatic environment in the Tulpehocken Creek basin supports the findings of previous studies by the Environmental Protection Agency (formerly the Federal Water Pollution Control Administration) (Geismar, 1968, written communication), and the Pennsylvania Department of Environmental Resources (Brezina, et al, 1974), which found that the watershed contained high concentrations of essential plant nutrients, bacteria of fecal origin, and industrial arsenical wastes.

Concentrations of nitrogen and phosphorus exceeded the minimum values suggested by Sawyer (1947) as critical for the nuisance growth of aquatic plants at a11 stations and in all samples, and was highest after storm runoff. Based upon estimates from a flow duration curve, the annual input of nitrogen and phosphorus to the lake is about 1,400 tons $(1,270$ metric tons) and 46 tons ( 41.7 metric tons), respectively.

Bacterial populations, indicative of the sanitary quality, generally exceed the State (Pa. Sanitary Water Board, 1967) and Federal (U.S. Dept. of the Interior, 1968) recommended standards for potable and water contact recreational use. The utility of the impoundment for the intended use of the water will be determined by how effectively bacterial populations are reduced by disinfection of waste waters and(or) by self purification. Given present bacterial populations and predicted retention time, the bacterial population will probably be at acceptable levels during periods of normal flow, but may exceed these levels when the inflows are above normal. 
Table 10.--Physical and chemical anatyses of soits

\begin{tabular}{|c|c|c|c|c|c|c|c|}
\hline \multirow{3}{*}{$\begin{array}{c}\text { Site } \\
\text { Description }\end{array}$} & \multirow{3}{*}{$\begin{array}{l}\text { Soil } \\
\text { Type }\end{array}$} & \multirow{3}{*}{ Sand } & \multirow{3}{*}{ Silt } & \multirow{3}{*}{ Clay } & \multicolumn{3}{|c|}{ Carbon } \\
\hline & & & & & $\begin{array}{l}\text { Inor- } \\
\text { ganic }\end{array}$ & $\begin{array}{l}\text { Or- } \\
\text { ganic }\end{array}$ & Tota1 \\
\hline & & & & & $\mathrm{P} \mathrm{E}$ & R C E & N T \\
\hline 0ld field-_- & Atkins & 26.0 & 25.0 & 49.0 & 0.1 & 1.5 & 1.6 \\
\hline Corn field- & Berks & 51.0 & 25.0 & 24.0 & 0.1 & 2.6 & 2.7 \\
\hline Pasture-- & Atkins & 29.0 & 41.0 & 30.0 & 0.0 & 2.8 & 2.8 \\
\hline Wooded area--- & Atkins & 17.0 & 51.0 & 32.0 & 0.2 & 2.1 & 2.3 \\
\hline 01d field- & Werkert-Berks & 40.0 & 31.0 & 29.0 & 0.0 & 1.3 & 1.3 \\
\hline
\end{tabular}


in the Tulpehocken Creek flood plain, June 13, 1973.

\begin{tabular}{|c|c|c|c|c|c|c|c|}
\hline \multicolumn{3}{|c|}{ Nitrogen } & \multicolumn{3}{|c|}{ Phosphorus } & \multirow[b]{2}{*}{$\begin{array}{c}\text { Carbon- } \\
\text { nitrogen } \\
\text { ratio }\end{array}$} & \multirow{2}{*}{$\begin{array}{c}\text { Nitrogen- } \\
\text { phos- } \\
\text { phorus } \\
\text { ratio } \\
\end{array}$} \\
\hline $\begin{array}{l}\text { Inor- } \\
\text { ganic }\end{array}$ & $\begin{array}{c}\text { Or- } \\
\text { ganic } \\
\mathrm{PER}\end{array}$ & $\frac{\text { Total }}{\mathrm{E} T \mathrm{~T}}$ & $\begin{array}{l}\text { Inor- } \\
\text { ganic }\end{array}$ & $\begin{array}{l}\text { Or- } \\
\text { ganic }\end{array}$ & Total & & \\
\hline- & -- & 0.13 & -- & -- & 0.002 & 12.3 & 65 \\
\hline- & -- & 0.19 & -- & -- & 0.014 & 14.2 & 13.6 \\
\hline-- & -- & 0.36 & -- & -- & 0.020 & 7.8 & 18 \\
\hline-- & -- & 0.46 & -- & -- & 0.024 & 5.0 & 19 \\
\hline-- & -- & 0.13 & -- & -- & 0.012 & 10.0 & 10.8 \\
\hline
\end{tabular}


Arsenic in the water, sediment, and bed material of Tulpehocken Creek represents a potential environmental hazard. Although concentrations of arsenic have been declining and did not exceed the National Interim Primary Drinking Water Standard of $50 \mu \mathrm{g} / \mathrm{L}$ nor the limits to be harmful to fish and wildlife, impoundment and anaerobic reduction of bottom mud could result in higher arsenic concentrations being released to the water column. 
Table 11.--Suspended sediment and arsenic concentration in Tulpehocken Creek at Blue Marsh Dam site near Reading, Pa.

\begin{tabular}{|c|c|c|c|c|c|c|}
\hline & & & & ent & Water & Total \\
\hline Date & Time & $\begin{array}{l}\text { Discharge } \\
\mathrm{ft}^{3} / \mathrm{s}\end{array}$ & $\begin{array}{l}\text { Sed conc } \\
\mathrm{mg} / \mathrm{L}\end{array}$ & $\begin{array}{c}\text { As conc } \\
\mu \mathrm{g} / \mathrm{g}\end{array}$ & $\begin{array}{c}\overline{\text { As conc }} \\
\mu \mathrm{g} / \mathrm{L}\end{array}$ & $\begin{array}{c}\text { As } \\
\mu \mathrm{g} / \mathrm{L}\end{array}$ \\
\hline $1 / 04 / 73$ & $\begin{array}{l}0925 \\
1250\end{array}$ & $\begin{array}{r}1,326 \\
887\end{array}$ & $\begin{array}{r}89 \\
116\end{array}$ & $\begin{array}{l}85 \\
22\end{array}$ & $\begin{array}{l}30 \\
20\end{array}$ & $\begin{array}{l}37.6 \\
22.6\end{array}$ \\
\hline $1 / 23$ & 1000 & 625 & 315 & 20 & 10 & 16.3 \\
\hline & 1425 & 526 & 314 & 7 & 10 & 12.2 \\
\hline & 1600 & 526 & 167 & 86 & 0 & 14.4 \\
\hline $1 / 24$ & 1050 & 446 & 39 & 36 & 10 & 11.4 \\
\hline & 1350 & 430 & 30 & 52 & 10 & 11.6 \\
\hline & 1650 & 423 & 32 & 70 & 10 & 12.2 \\
\hline $1 / 28$ & 1600 & 543 & 286 & 7 & 10 & 12.0 \\
\hline $1 / 29$ & 1000 & 1,550 & 210 & 12 & 10 & 12.5 \\
\hline & 1600 & 1,310 & 214 & 11 & 10 & 12.4 \\
\hline $1 / 30$ & 1600 & 761 & 55 & 44 & 10 & 12.4 \\
\hline $2 / 02$ & 1600 & 1,230 & 412 & 20 & 10 & 18.2 \\
\hline $3 / 08$ & 1600 & 288 & 15 & 123 & 10 & 11.8 \\
\hline $3 / 26$ & 0900 & 667 & 73 & 91 & 20 & 26.6 \\
\hline & 1200 & 589 & 75 & 58 & 20 & 24.4 \\
\hline & 1600 & 493 & 80 & 44 & 20 & 23.5 \\
\hline $3 / 27$ & 0900 & 340 & 25 & 126 & 10 & 13.2 \\
\hline & 1200 & 335 & 14 & 157 & 20 & 22.2 \\
\hline $3 / 30$ & 1600 & 326 & 7 & 240 & 10 & 11.9 \\
\hline $4 / 01$ & 1600 & 537 & 288 & 15 & 30 & 34.3 \\
\hline 4/03 & 1600 & 983 & 85 & 28 & 20 & 22.4 \\
\hline
\end{tabular}


Table 11.--Suspended sediment and arsenic concentration in Tulpehocken Creek at Blue Marsh Dam site near Reading, Pa.--continued.

\begin{tabular}{|c|c|c|c|c|c|c|}
\hline \multirow[b]{2}{*}{ Date } & \multirow[b]{2}{*}{ Time } & \multirow[b]{2}{*}{$\begin{array}{l}\text { Discharge } \\
\mathrm{ft}^{3} / \mathrm{s}\end{array}$} & \multicolumn{2}{|c|}{ Sediment } & Water & \multirow{2}{*}{$\begin{array}{l}\text { Total } \\
\text { As } \\
\mu \mathrm{g} / \mathrm{L}\end{array}$} \\
\hline & & & $\begin{array}{l}\text { Sed conc } \\
\mathrm{mg} / \mathrm{L}\end{array}$ & $\begin{array}{c}\text { As conc } \\
\mu \mathrm{g} / \mathrm{g}\end{array}$ & $\begin{array}{c}\overline{\text { As conc }} \\
\mu \mathrm{g} / \mathrm{L}\end{array}$ & \\
\hline $4 / 04 / 73$ & $\begin{array}{l}1300 \\
1600\end{array}$ & $\begin{array}{r}819 \\
1,190\end{array}$ & $\begin{array}{l}136 \\
136\end{array}$ & $\begin{array}{l}35 \\
39\end{array}$ & $\begin{array}{l}10 \\
20\end{array}$ & $\begin{array}{l}14.8 \\
25.3\end{array}$ \\
\hline $4 / 05$ & 1600 & 1,102 & 98 & 77 & $<5$ & 12.6 \\
\hline $4 / 08$ & 1600 & 1,086 & 45 & 71 & 10 & 13.2 \\
\hline $4 / 10$ & $\begin{array}{l}1000 \\
1300 \\
1600\end{array}$ & $\begin{array}{l}2,396 \\
2,261 \\
1,685\end{array}$ & $\begin{array}{l}301 \\
304 \\
536\end{array}$ & $\begin{array}{l}52 \\
33 \\
19\end{array}$ & $\begin{array}{l}10 \\
<5 \\
20\end{array}$ & $\begin{array}{l}25.7 \\
15.0 \\
30.2\end{array}$ \\
\hline $4 / 26$ & 1600 & 499 & 34 & 75 & 20 & 22.6 \\
\hline $4 / 27$ & 1600 & 376 & 17 & 74 & 10 & 11.3 \\
\hline $4 / 28$ & 1600 & 1,015 & 19 & 180 & 10 & 13.4 \\
\hline $5 / 09$ & 1600 & 314 & 32 & 42 & 10 & 11.3 \\
\hline $5 / 21$ & $\begin{array}{l}0850 \\
1250 \\
1800\end{array}$ & $\begin{array}{l}420 \\
372 \\
349\end{array}$ & $\begin{array}{l}88 \\
56 \\
44\end{array}$ & $\begin{array}{r}38 \\
71 \\
244\end{array}$ & $\begin{array}{l}10 \\
10 \\
10\end{array}$ & $\begin{array}{l}13.3 \\
14.0 \\
20.7\end{array}$ \\
\hline $5 / 22$ & 0925 & 314 & 21 & 229 & 10 & 14.8 \\
\hline $5 / 25$ & 1900 & 358 & 45 & 368 & 0 & 16.6 \\
\hline $5 / 27$ & 1850 & 326 & 18 & 879 & 0 & 15.8 \\
\hline $5 / 29$ & $\begin{array}{l}1325 \\
1750 \\
1950\end{array}$ & $\begin{array}{l}2,081 \\
1,595 \\
1,478\end{array}$ & $\begin{array}{l}283 \\
207 \\
161\end{array}$ & $\begin{array}{r}137 \\
30 \\
44\end{array}$ & $\begin{array}{l}10 \\
10 \\
10\end{array}$ & $\begin{array}{l}48.8 \\
16.2 \\
17.1\end{array}$ \\
\hline $5 / 30$ & $\begin{array}{l}0850 \\
1350 \\
1950\end{array}$ & $\begin{array}{r}1,094 \\
987 \\
866\end{array}$ & $\begin{array}{r}107 \\
98 \\
90\end{array}$ & $\begin{array}{l}41 \\
11 \\
24\end{array}$ & $\begin{array}{r}10 \\
10 \\
0\end{array}$ & $\begin{array}{r}14.4 \\
11.1 \\
2.2\end{array}$ \\
\hline
\end{tabular}


Table 11.--Suspended sediment and arsenic concentration in Tulpehocken Creek at Blue Marsh Dam site near Reading, Pa.--continued.

\begin{tabular}{|c|c|c|c|c|c|c|}
\hline \multirow[b]{2}{*}{ Date } & \multirow[b]{2}{*}{ Time } & \multirow[b]{2}{*}{$\begin{array}{c}\text { Discharge } \\
\mathrm{ft} / \mathrm{s}\end{array}$} & \multicolumn{2}{|c|}{ Sediment } & Water & \multirow{2}{*}{$\begin{array}{c}\text { Total } \\
\text { As } \\
\mu \mathrm{g} / \mathrm{L}\end{array}$} \\
\hline & & & $\begin{array}{l}\text { Sed conc } \\
\mathrm{mg} / \mathrm{L}\end{array}$ & $\begin{array}{c}\text { As conc } \\
\mu \mathrm{g} / \mathrm{g}\end{array}$ & $\begin{array}{c}\overline{\text { As conc }} \\
\mu \mathrm{g} / \mathrm{L}\end{array}$ & \\
\hline $5 / 31 / 73$ & 1900 & 915 & 108 & 36 & 10 & 13.9 \\
\hline $6 / 06$ & 2000 & 381 & 61 & 69 & 10 & 14.2 \\
\hline $6 / 07$ & $\begin{array}{l}1150 \\
1600\end{array}$ & $\begin{array}{l}1,510 \\
1,150\end{array}$ & $\begin{array}{l}1,680 \\
1,370\end{array}$ & $\begin{array}{l}3 \\
3\end{array}$ & $\begin{array}{l}10 \\
10\end{array}$ & $\begin{array}{l}15.0 \\
14.1\end{array}$ \\
\hline $6 / 13$ & 1850 & 440 & 1,850 & 2 & 10 & 13.7 \\
\hline $6 / 22$ & $\begin{array}{l}0850 \\
1800\end{array}$ & $\begin{array}{r}1,086 \\
372\end{array}$ & $\begin{array}{r}1,680 \\
498\end{array}$ & $\begin{array}{l}4 \\
8\end{array}$ & $\begin{array}{l}0 \\
0\end{array}$ & $\begin{array}{l}6.7 \\
3.9\end{array}$ \\
\hline $6 / 23$ & 1850 & 340 & 69 & 58 & 10 & 14.0 \\
\hline $6 / 24$ & 2050 & 292 & 49 & 42 & 10 & 12.1 \\
\hline $6 / 29$ & 1600 & 4,300 & 1,330 & 0 & 0 & 0 \\
\hline $6 / 30$ & 1850 & 735 & 83 & 37 & 10 & 13.1 \\
\hline $7 / 03$ & $\begin{array}{l}1450 \\
2000\end{array}$ & $\begin{array}{l}482 \\
868\end{array}$ & $\begin{array}{r}86 \\
393\end{array}$ & $\begin{array}{l}23 \\
24\end{array}$ & $\begin{array}{l}10 \\
10\end{array}$ & $\begin{array}{l}12.0 \\
19.4\end{array}$ \\
\hline $7 / 05$ & $\begin{array}{l}1100 \\
1500 \\
1900\end{array}$ & $\begin{array}{l}625 \\
521 \\
482\end{array}$ & $\begin{array}{r}149 \\
193 \\
91\end{array}$ & $\begin{array}{l}44 \\
48 \\
46\end{array}$ & $\begin{array}{l}10 \\
10 \\
10\end{array}$ & $\begin{array}{l}16.6 \\
19.3 \\
14.2\end{array}$ \\
\hline $1 / 17 / 74$ & 1700 & 360 & 24 & 81 & 8 & 9.9 \\
\hline $1 / 21$ & 1900 & 1,302 & 492 & 10 & 6 & 10.9 \\
\hline $2 / 20$ & $\begin{array}{l}0900 \\
1300 \\
1600\end{array}$ & $\begin{array}{l}369 \\
333 \\
555\end{array}$ & $\begin{array}{l}98 \\
51 \\
36\end{array}$ & $\begin{array}{l}66 \\
67 \\
69\end{array}$ & $\begin{array}{l}6 \\
7 \\
7\end{array}$ & $\begin{array}{r}12.5 \\
10.4 \\
9.5\end{array}$ \\
\hline
\end{tabular}


Table 11.--Suspended sediment and arsenic concentration in Tulpehocken Creek at Blue Marsh Dam site near Reading, Pa.--continued.

\begin{tabular}{|c|c|c|c|c|c|c|}
\hline \multirow[b]{2}{*}{ Date } & \multirow[b]{2}{*}{ Time } & \multirow[b]{2}{*}{$\begin{array}{l}\text { Discharge } \\
\mathrm{ft}^{3} / \mathrm{s}\end{array}$} & \multicolumn{2}{|c|}{ Sediment } & Water & \multirow{2}{*}{$\begin{array}{l}\text { Total } \\
\text { As } \\
\mu \mathrm{g} / \mathrm{L}\end{array}$} \\
\hline & & & $\begin{array}{l}\text { Sed conc } \\
\mathrm{mg} / \mathrm{L}\end{array}$ & $\begin{array}{c}\text { As conc } \\
\mu \mathrm{g} / \mathrm{g}\end{array}$ & $\begin{array}{c}\text { As conc } \\
\mu \mathrm{g} / \mathrm{L}\end{array}$ & \\
\hline $2 / 22 / 74$ & 1800 & 500 & 99 & 36 & 8 & 11.6 \\
\hline $3 / 09$ & 1550 & 355 & 72 & 35 & 4 & 6.5 \\
\hline $3 / 21$ & 1650 & 555 & 54 & 72 & 5 & 8.9 \\
\hline $3 / 31$ & 1350 & 940 & 186 & 39 & 8 & 15.3 \\
\hline 4/04 & $\begin{array}{l}1550 \\
1800 \\
2000\end{array}$ & $\begin{array}{l}1,712 \\
1,595 \\
1,510\end{array}$ & $\begin{array}{l}707 \\
549 \\
459\end{array}$ & $\begin{array}{l}36 \\
51 \\
63\end{array}$ & $\begin{array}{l}7 \\
8 \\
9\end{array}$ & $\begin{array}{l}32.5 \\
36.0 \\
37.9\end{array}$ \\
\hline 4/05 & $\begin{array}{l}1600 \\
1850 \\
2000\end{array}$ & $\begin{array}{l}1,390 \\
1,542 \\
1,518\end{array}$ & $\begin{array}{l}181 \\
301 \\
285\end{array}$ & $\begin{array}{l}57 \\
53 \\
50\end{array}$ & $\begin{array}{l}6 \\
5 \\
6\end{array}$ & $\begin{array}{l}16.3 \\
20.9 \\
20.3\end{array}$ \\
\hline 4/06 & $\begin{array}{l}1000 \\
1600 \\
2000\end{array}$ & $\begin{array}{r}1,066 \\
975 \\
913\end{array}$ & $\begin{array}{r}129 \\
71 \\
66\end{array}$ & $\begin{array}{l}63 \\
75 \\
64\end{array}$ & $\begin{array}{l}7 \\
8 \\
8\end{array}$ & $\begin{array}{l}15.1 \\
13.3 \\
12.2\end{array}$ \\
\hline 4/09 & 1650 & 773 & 47 & 98 & 8 & 12.6 \\
\hline $5 / 13$ & 1700 & 567 & 100 & 24 & 14 & 16.4 \\
\hline $7 / 30$ & 1600 & 204 & 58 & 19 & 13 & 14.1 \\
\hline $8 / 03$ & $\begin{array}{l}1200 \\
1600 \\
2000\end{array}$ & $\begin{array}{l}239 \\
180 \\
157\end{array}$ & $\begin{array}{r}166 \\
60 \\
53\end{array}$ & $\begin{array}{l}16 \\
14 \\
27\end{array}$ & $\begin{array}{l}11 \\
14 \\
20\end{array}$ & $\begin{array}{l}13.6 \\
14.8 \\
21.4\end{array}$ \\
\hline $8 / 04$ & $\begin{array}{l}1250 \\
1700\end{array}$ & $\begin{array}{l}204 \\
192\end{array}$ & $\begin{array}{l}60 \\
47\end{array}$ & $\begin{array}{l}22 \\
29\end{array}$ & $\begin{array}{l}20 \\
15\end{array}$ & $\begin{array}{l}21.3 \\
16.4\end{array}$ \\
\hline $8 / 05$ & $\begin{array}{l}1500 \\
1850\end{array}$ & $\begin{array}{l}135 \\
119\end{array}$ & $\begin{array}{l}24 \\
21\end{array}$ & $\begin{array}{l}35 \\
28\end{array}$ & $\begin{array}{l}16 \\
17\end{array}$ & $\begin{array}{l}16.8 \\
17.6\end{array}$ \\
\hline
\end{tabular}


Table 11.--Suspended sediment and arsenic concentration in Tulpehocken Creek at Blue Marsh Dam site near Reading, Pa.--continued.

\begin{tabular}{|c|c|c|c|c|c|c|}
\hline \multirow[b]{2}{*}{ Date } & \multirow[b]{2}{*}{ Time } & \multirow[b]{2}{*}{$\begin{array}{l}\text { Discharge } \\
\mathrm{ft}^{3} / \mathrm{s}\end{array}$} & \multicolumn{2}{|c|}{ Sediment } & Water & \multirow{2}{*}{$\begin{array}{c}\text { Total } \\
\text { As } \\
\mu \mathrm{g} / \mathrm{L}\end{array}$} \\
\hline & & & $\begin{array}{l}\text { Sed conc } \\
\mathrm{mg} / \mathrm{L}\end{array}$ & $\begin{array}{c}\text { As conc } \\
\mu \mathrm{g} / \mathrm{g}\end{array}$ & $\begin{array}{c}\overline{\text { As conc }} \\
\mu \mathrm{g} / \mathrm{L}\end{array}$ & \\
\hline $8 / 10 / 74$ & $\begin{array}{l}1350 \\
1600 \\
2050\end{array}$ & $\begin{array}{l}119 \\
113 \\
107\end{array}$ & $\begin{array}{r}104 \\
52 \\
36\end{array}$ & $\begin{array}{l}19 \\
24 \\
33\end{array}$ & $\begin{array}{l}11 \\
17 \\
17\end{array}$ & $\begin{array}{l}13.0 \\
18.2 \\
18.2\end{array}$ \\
\hline $8 / 17$ & 1900 & 166 & 167 & 15 & 15 & 17.5 \\
\hline $8 / 18$ & 0900 & 119 & 69 & 19 & 14 & 15.1 \\
\hline $8 / 30$ & 2000 & 101 & 20 & 27 & 18 & 18.5 \\
\hline 9/03 & $\begin{array}{l}1050 \\
1500\end{array}$ & $\begin{array}{l}135 \\
139\end{array}$ & $\begin{array}{l}55 \\
42\end{array}$ & $\begin{array}{l}23 \\
24\end{array}$ & $\begin{array}{l}15 \\
22\end{array}$ & $\begin{array}{l}16.3 \\
23.0\end{array}$ \\
\hline 9/04 & $\begin{array}{l}0850 \\
1350 \\
1800\end{array}$ & $\begin{array}{l}252 \\
219 \\
200\end{array}$ & $\begin{array}{r}119 \\
58 \\
60\end{array}$ & $\begin{array}{l}20 \\
17 \\
19\end{array}$ & $\begin{array}{l}15 \\
18 \\
17\end{array}$ & $\begin{array}{l}17.4 \\
19.0 \\
18.1\end{array}$ \\
\hline $9 / 05$ & $\begin{array}{l}0850 \\
1300\end{array}$ & $\begin{array}{l}145 \\
135\end{array}$ & $\begin{array}{l}45 \\
26\end{array}$ & $\begin{array}{l}31 \\
31\end{array}$ & $\begin{array}{l}21 \\
14\end{array}$ & $\begin{array}{l}22.4 \\
14.8\end{array}$ \\
\hline $9 / 07$ & $\begin{array}{l}1550 \\
1900\end{array}$ & $\begin{array}{l}298 \\
307\end{array}$ & $\begin{array}{l}163 \\
162\end{array}$ & $\begin{array}{l}22 \\
19\end{array}$ & $\begin{array}{l}11 \\
11\end{array}$ & $\begin{array}{l}14.6 \\
14.1\end{array}$ \\
\hline 9/08 & $\begin{array}{l}1250 \\
1700\end{array}$ & $\begin{array}{l}177 \\
170\end{array}$ & $\begin{array}{r}202 \\
38\end{array}$ & $\begin{array}{l}24 \\
22\end{array}$ & $\begin{array}{l}14 \\
18\end{array}$ & $\begin{array}{l}18.8 \\
18.8\end{array}$ \\
\hline 9/09 & 1200 & 152 & 87 & 24 & 17 & 19.0 \\
\hline $11 / 07$ & 1700 & 84 & 420 & 7 & 4 & 6.9 \\
\hline $11 / 13$ & $\begin{array}{l}0900 \\
1250 \\
1700\end{array}$ & $\begin{array}{l}170 \\
170 \\
149\end{array}$ & $\begin{array}{l}60 \\
24 \\
20\end{array}$ & $\begin{array}{l}14 \\
23 \\
15\end{array}$ & $\begin{array}{l}5 \\
5 \\
4\end{array}$ & $\begin{array}{l}5.8 \\
5.6 \\
4.3\end{array}$ \\
\hline $12 / 08$ & $\begin{array}{l}1100 \\
1400 \\
1700\end{array}$ & $\begin{array}{l}190 \\
266 \\
438\end{array}$ & $\begin{array}{l}425 \\
636 \\
933\end{array}$ & $\begin{array}{l}8 \\
7 \\
5\end{array}$ & $\begin{array}{l}5 \\
5 \\
5\end{array}$ & $\begin{array}{l}8.0 \\
9.5 \\
9.7\end{array}$ \\
\hline
\end{tabular}


Table 11.--Suspended sediment and arsenic concentration in Tulpehocken Creek at Blue Marsh Dam site near Reading, Pa.--continued.

\begin{tabular}{|c|c|c|c|c|c|c|}
\hline \multirow[b]{2}{*}{ Date } & \multirow[b]{2}{*}{ Time } & \multirow[b]{2}{*}{$\begin{array}{l}\text { Dischharge } \\
\mathrm{ft}^{3} / \mathrm{s}\end{array}$} & \multicolumn{2}{|c|}{ Sediment } & Water & \multirow{2}{*}{$\begin{array}{c}\text { Total } \\
\text { As } \\
\mu \mathrm{g} / \mathrm{L}\end{array}$} \\
\hline & & & $\begin{array}{l}\text { Sed conc } \\
\mathrm{mg} / \mathrm{L}\end{array}$ & $\begin{array}{c}\text { As conc } \\
\mu \mathrm{g} / \mathrm{g}\end{array}$ & $\begin{array}{c}\overline{\text { As conc }} \\
\mu \mathrm{g} / \mathrm{L}\end{array}$ & \\
\hline $12 / 09 / 74$ & $\begin{array}{l}0900 \\
1300 \\
1700\end{array}$ & $\begin{array}{l}664 \\
578 \\
529\end{array}$ & $\begin{array}{r}195 \\
110 \\
82\end{array}$ & $\begin{array}{l}13 \\
22 \\
10\end{array}$ & $\begin{array}{l}6 \\
5 \\
3\end{array}$ & $\begin{array}{l}8.5 \\
7.4 \\
3.8\end{array}$ \\
\hline $12 / 10$ & $\begin{array}{l}0900 \\
1300 \\
1700\end{array}$ & $\begin{array}{l}395 \\
375 \\
358\end{array}$ & $\begin{array}{l}43 \\
33 \\
41\end{array}$ & $\begin{array}{l}17 \\
21 \\
13\end{array}$ & $\begin{array}{l}6 \\
7 \\
7\end{array}$ & $\begin{array}{l}6.7 \\
7.7 \\
7.5\end{array}$ \\
\hline $12 / 11$ & $\begin{array}{l}0900 \\
1300 \\
1700\end{array}$ & $\begin{array}{l}312 \\
296 \\
281\end{array}$ & $\begin{array}{l}30 \\
25 \\
23\end{array}$ & $\begin{array}{l}23 \\
17 \\
18\end{array}$ & $\begin{array}{r}10 \\
10 \\
8\end{array}$ & $\begin{array}{r}10.7 \\
10.4 \\
8.4\end{array}$ \\
\hline $12 / 16$ & $\begin{array}{l}1250 \\
1500 \\
1700\end{array}$ & $\begin{array}{l}256 \\
354 \\
741\end{array}$ & $\begin{array}{r}84 \\
190 \\
556\end{array}$ & $\begin{array}{r}14 \\
13 \\
7\end{array}$ & $\begin{array}{l}7 \\
7 \\
5\end{array}$ & $\begin{array}{l}8.2 \\
9.5 \\
8.9\end{array}$ \\
\hline $12 / 17$ & $\begin{array}{l}0900 \\
1300 \\
1650\end{array}$ & $\begin{array}{l}963 \\
629 \\
578\end{array}$ & $\begin{array}{r}155 \\
110 \\
91\end{array}$ & $\begin{array}{l}26 \\
17 \\
10\end{array}$ & $\begin{array}{l}7 \\
7 \\
7\end{array}$ & $\begin{array}{r}11.0 \\
8.9 \\
7.9\end{array}$ \\
\hline $12 / 18$ & $\begin{array}{l}0900 \\
1250 \\
1650\end{array}$ & $\begin{array}{l}483 \\
474 \\
461\end{array}$ & $\begin{array}{l}54 \\
48 \\
45\end{array}$ & $\begin{array}{l}18 \\
11 \\
18\end{array}$ & $\begin{array}{l}8 \\
8 \\
7\end{array}$ & $\begin{array}{l}9.0 \\
8.5 \\
7.8\end{array}$ \\
\hline $1 / 09 / 75$ & $\begin{array}{l}0900 \\
1250 \\
1600\end{array}$ & $\begin{array}{r}247 \\
545 \\
1,100\end{array}$ & $\begin{array}{l}172 \\
513 \\
327\end{array}$ & $\begin{array}{l}27 \\
26 \\
29\end{array}$ & $\begin{array}{l}4 \\
4 \\
3\end{array}$ & $\begin{array}{r}8.6 \\
17.3 \\
12.5\end{array}$ \\
\hline $1 / 10$ & 0950 & 642 & 89 & 43 & 4 & 7.8 \\
\hline $1 / 11$ & 1600 & 600 & 58 & 44 & 7 & 9.6 \\
\hline $1 / 12$ & 1700 & 474 & 40 & 54 & 10 & 12.2 \\
\hline $2 / 25$ & 0900 & 798 & 272 & 32 & 9 & 17.7 \\
\hline
\end{tabular}


Table 11.--Suspended sediment and arsenic concentration in Tulpehocken Creek at Blue Marsh Dam site near Reading, Pa.--continued.

\begin{tabular}{|c|c|c|c|c|c|c|}
\hline \multirow[b]{2}{*}{ Date } & \multirow[b]{2}{*}{ Time } & \multirow[b]{2}{*}{$\begin{array}{c}\text { Discharge } \\
\mathrm{ft}^{3} / \mathrm{s}\end{array}$} & \multicolumn{2}{|c|}{ Sediment } & Water & \multirow{2}{*}{$\begin{array}{c}\text { Total } \\
\text { As } \\
\mu \mathrm{g} / \mathrm{L}\end{array}$} \\
\hline & & & $\begin{array}{l}\text { Sed conc } \\
\mathrm{mg} / \mathrm{L}\end{array}$ & $\begin{array}{c}\text { As conc } \\
\mu \mathrm{g} / \mathrm{g}\end{array}$ & $\begin{array}{c}\overline{\text { As conc }} \\
\mu \mathrm{g} / \mathrm{L}\end{array}$ & \\
\hline $2 / 26 / 75$ & 0900 & 1,042 & 92 & 37 & 6 & 9.4 \\
\hline $2 / 27$ & 0900 & 798 & 49 & 46 & 9 & 11.3 \\
\hline $3 / 19$ & 1800 & 458 & 124 & 39 & 5 & 9.8 \\
\hline $3 / 20$ & 1000 & 1,752 & 380 & 39 & 6 & 20.8 \\
\hline $3 / 21$ & 0900 & 1,048 & 77 & 51 & 8 & 11.9 \\
\hline $4 / 05$ & 1450 & 720 & 67 & 52 & 5 & 8.5 \\
\hline $4 / 26$ & 0950 & 756 & 63 & 19 & 6 & 7. \\
\hline
\end{tabular}


Ackerman, F. S., 1970, Soil survey of Berks County, Pennsylvania: U.S. Soil Conserv. Serv., 125 p.

Biesecker, J. E., Lescinsky, J. B., and Wood, C. R., 1968, Water resources of the Schuylkill River basin: Pennsylvania Dept. Environmental

Resources Bull. no. 3, 198 p.

Brezina, E. R., Sheaffer, K. K., and Ulanoski, J. T., 1974, Schuy1ki11 River basin water quality: Pennsylvania Dept。Environmental Resources Pub. 34, 281 p.

Brown, Eugene, Skougstad, M. W., and Fishman, M. J., 1970, Methods for collection and analysis of water samples for dissolved minerals and gases: U.S. Geol. Survey Techniques Water Resources Inv., book 3, chap. Al, $160 \mathrm{p}$.

Cooper, E. L., 1967, A symposium on water quality to protect aquatic life: Am. Fisheries Soc. Spec. Pub. no. 4.

E11is, M. M., 1937, Detection and measurement of stream pollution: Bur. Fisheries Bul1. 4.48, 365437 p.

Faust, S. D., and Clement, W. H., 1973, Investigation of the arsenic conditions at the Blue Marsh Lake project site: Pennsylvania Dept. of Environmental Sciences, Rutgers, The State Univ., New Brunswick, N.J., mimeo rept., 114 p.

Flippo, H. N., Jr., 1970, Chemical and biological conditions in Bald Eagle Creek and prognosis of trophic characteristics of Foster Joseph Sayers Reservoir, Centre County, Pennsylvania: U.S. Geol。Survey open-file rept., $48 \mathrm{p}$.

Geismar, Edward V., 1968, Blue Marsh Reservoir preimpoundment water quality: written communication.

Goerlitz, D. F., and Brown, Eugene, 1972, Methods for analysis of organic substance in water: U.S. Geol. Survey Techniques of Water-Resources Inv., book 5, chap. A3, 40 p.

Greeson, Phillip E., 1971, Limnology of Oneida Lake with emphasis on factors contributing to algae blooms: U.S. Geol. Survey open-file rept., 185 p.

Guy, Harold P., 1969, Laboratory theory and methods for sediment analyses: U.S. Geol. Survey Techniques of Water Resources Inv., book 5, chap. C1, $58 \mathrm{p}$.

Lyon, T. L., Buckman, H. O., and Brady, N. C., 1952, The nature and properties of soils: New York, MacMillan, 591 p. 
McKee, J. E., and Wolf, H. W., 1971, Water quality criteria (2nd ed.): Resources Agency of California, State Water Resources Control Board, pub. no. $3 \mathrm{~A}, 548 \mathrm{p}$.

Pennsylvania Sanitary Water Board, 1967, Water quality criteria: Pennsylvania Sanitary Water Board Art. 301.

Sawyer, C. N., 1947, Fertilization of lakes by agricultural and urban drainage: New England Water Works Assoc. Jour., vol. 61, p. 109-127.

Sculthrope, C. D., 1967, The biology of aquatic vascular plants: London, Edward Arnold, 610 p.

Slack, K. V., Averett, R. D., Greeson, R. G., and Lipscomb, R. G., 1973, Methods for collection and analysis of aquatic biological and microbiological samples: U.S. Geol. Survey Techniques Water Resources Inv., book 3, chap. A4, 165 p.

Smith, R. J., and Twedt, R. M., 1971, Natural relationships of indicator and pathogenic bacteria in stream waters: Water Pollution Control Federation Jour., vo1. 43, no. 11, p. 2200-2209。

U.S. Dept. of the Army, Philadelphia District, Corps of Engineers, 1973, Blue Marsh Lake: Water Quality Report, 85 p.

U.S. Dept. of the Interior, 1968, Water quality criteria: Water Pollution Control Admin., U.S. Dept. of the Interior, Washington, D. C.

Wood, C. R., 1973, An evaluation of arsenic concentrations in the Tulpehocken Creek basin, Pennsylvania: U.S. Geol. Survey open-file rept., 16 p. 